\title{
Composition of bird nests is a species-specific characteristic
}

\author{
Lucia E. Biddle*, Robyn E. Broughton, Adrian M. Goodman and D. Charles Deeming* \\ School of Life Sciences, University of Lincoln, Joseph Banks Laboratories, Lincoln, LN6 7DL, UK
}

*Corresponding authors email: lbiddle@lincoln.ac.uk; cdeeming@lincoln.ac.uk

Running headline: bird nest composition

\begin{abstract}
Bird nests represent an extended phenotype of individuals expressed during reproduction and so exhibit variability in composition, structure and function. Descriptions of nests based on qualitative observations suggest that there is interspecific variation in size and composition but there are very few species in which this has been confirmed. For these species, data of the amounts of different materials indicate that nest construction behaviour is plastic and affected by a variety of factors, such as prevailing temperature, geographic location, and availability of materials. The lack of data on nest composition is hampering our understanding of how nests achieve their various functions and how different species solve the problem of building a nest that will accommodate incubation and allow successful hatching of eggs. This study deconstructed nests of four species of the Turdidae, four species of the Muscicapidae, and six species of the Fringillidae and quantified the size of the nests and their composition. These data were used to test: 1) whether nest size correlated with adult bird mass; 2) whether it was possible to distinguish between species on the basis of their nest composition; and 3) whether, within a species, it was possible to distinguish between the cup lining and the rest of the nest based on composition. Most but not all nest dimensions correlated with bird mass. Principal component analysis revealed species differences based on nest composition and discriminant analysis could distinguish cup lining from the outer nest based on material composition. Intraspecific variation in composition varied among species and in general fewer types of material were found in the cup lining than the outer nest. These data provide insight into how nests are constructed by the different species and in conjunction with studies of the mechanical, thermal and hydrological properties of a nest, will begin to reveal how and why individual species select particular combinations of materials to build a nest.
\end{abstract}

Keywords: Bird nest, composition, dimensions, Fringillidae, Muscicapidae, Turdidae.

\section{INTRODUCTION}

Birds construct nests in a variety of different shapes, such as cups, domes, scrapes, or burrows and these act as an extended phenotype (Collias and Collias, 1984; Hansell, 2000). The role of nests has been attributed to receptacles for eggs and chicks, through to a key element of incubation (Deeming, 2016) as well as acting as signals of fitness (Moreno, 2012; Mainwaring, 2015). Although qualitative descriptions of nest compositions are made for a wide range of species (for example Ferguson-Lees et al., 2011), quantitative data on the amounts of materials used in nest construction is very limited (Deeming and Mainwaring, 2015). However, such data is of interest because there is an increasing body of evidence that nest construction is a plastic phenotype between individual birds (e.g., 
Walsh et al., 2011), between years (Britt and Deeming, 2011), and between geographical locations (Briggs and Deeming, 2016).

The bird nest is a bio-engineered structure that is heterogeneous not only in its composition, but also in the roles each component plays in the function of the nests as a whole. Hansell (2000) defined nests as being composed of four functionally distinct areas: an attachment, an outer (decorative) layer, a structural layer and a lining, although not all are present in all nests. Whilst lining materials presumably provide insulation for the eggs/chicks (Mainwaring and Hartley, 2008), the structural layer provides nest shape and integrity preventing the nest from falling apart (Hansell, 2000). However, few studies have investigated how differing nest materials are used in different parts of the nest and the behaviours underpinning nest construction are only reported for a few species (Healy et al., 2015). For instance, the diameter, strength and rigidity of materials differed between parts of the nest in Common Blackbirds (Turdus merula) and the Eurasian Bullfinch (Pyrrhula pyrrhula), and was considered to reflect mechanical requirements of the structure (Biddle et al., 2015, 2017). More broadly we know that there is intra-specific variation in the materials used to construct nests within the same habitat (Britt and Deeming, 2011; Álvarez et al., 2013). However, a better understanding of variability in composition will also allow us to understand factors affecting intraspecific variation between different habitats (e.g. Calvelo et al., 2006; Crossman et al., 2011; Álvarez et al., 2013; Mainwaring et al., 2014b; Taberner Cerezo and Deeming, 2016; Briggs and Deeming, 2016).

There is evidence that composition of nests reflects the materials present within the local environment (Surgey et al., 2012; Briggs and Deeming, 2016). Pied flycatchers were shown to use leaves in their nests from the trees growing immediately outside the nestbox they use (Briggs and Deeming, 2016) while Blue Tits (Cyanistes caeruleus) and Great Tits (Parus major) nests have been shown to have a higher proportion of wool within them during a year when sheep were within the local area (Britt and Deeming, 2011). By contrast, there are reports that indicate species can be very specific in the materials that use in their nests. For example, many birds incorporate materials with known anti-parasite or anti-pathogen properties (Ontiveros et al., 2008; Dubiec et al., 2013; Mainwaring et al., 2014a; Suárez-Rodríguez et al., 2013).

Larger bird species build larger nests compared to smaller bird species, yet changes in nest dimensions are all not in proportion (Slagsvold, 1989a; Hansell, 2000; Heenan and Seymour, 2011; Deeming, 2013). Female body mass has a greater effect on dimensions, such as nest diameter and height, than others, such as cup diameter and depth. However, nests exhibit intraspecific variation in size and composition associated with biotic factors, e.g. male weaverbirds exhibit low repeatability in nest construction (Walsh et al., 2010), and various abiotic factors, for instance altitude and climate. Nests found at higher elevations have been showed to be larger with greater insulatory properties (Kern and Van Riper, 1984; Janiga and Višňovská, 2004). Nests constructed in colder locations and earlier in the breeding season when the temperature is lower are larger in size than those constructed in warmer locations or later in the breeding season when the average temperature is higher (Powell and Rangen, 2000; Rohwer and Law, 2010; Britt and Deeming, 2011; Crossman et al., 2011; Mainwaring et al., 2012, 2014b; Deeming et al., 2012; Malzer and Hansell, 2017). Nest behaviour is, therefore, a plastic behaviour affected by a variety of biotic and abiotic factors.

There are approximately 10,000 species of bird species. Although nest size is available for at least 325 species (Deeming, 2013), the quantity of materials birds use during nest construction is only known for 14 species (Deeming and Mainwaring, 2015; Taberner Cerezo and Deeming, 2015; Briggs and Deeming, 2016). 
Unfortunately, paucity of data is limiting our understanding of evolutionary patterns in nest construction, i.e. do closely related species tend to build nests of similar composition? Moreover, we have little understanding of how size and/or composition of nests affect their different functions, e.g. thermal, structural or hydrological properties.

This report describes nest composition of six species of finch from the Fringillidae and four species of thrush from the Turdidae and two species of Old World flycatcher from the Muscicapidae, plus previous reported data for the European Robin (Erithacus rubecula) and Pied Flycatcher (Ficedula hypoleuca) which are also from the Muscicapidae (Taberner Cerezo and Deeming, 2015; Briggs and Deeming, 2016). Quantitative data on nest composition were previously unavailable for all species except for the Common Blackbird (Turdus merula; see Deeming and Mainwaring, 2015); some of the data included here for the Eurasian Bullfinch (Pyrrhula pyrrhula) were reported in Biddle et al. (2017). Whilst these data will be useful in understanding the mechanical, thermal and hydrological properties of nests from these species, we can also test a variety of hypotheses about intraspecific and intrafamily variability. Firstly, nest dimensions should correlate with body size. Secondly, field guides of nests (Harrison 1975, 1978; Ferguson-Lees et al., 2011) suggest that composition is diagnostic of species. Quantitative data for construction materials reported here allow us to test the hypothesis that it is possible to distinguish between species, and/or families, based on their nest composition. Finally, Hansell (2000) indicated that nests have different structural elements with specific characteristics. However, it cannot be assumed that although a cup can be distinguished from the outer nest, this is the result of difference composition. Rather it may reflect differences in the size of materials or how they are incorporated into the structure. Therefore, we test whether, for individual species, it is possible to distinguish between parts of a nest based on the materials used in construction.

\section{METHODS}

\subsection{Nests}

Nests were studied from species representing three different families; six finch species of the Fringillidae, and four thrush of the Turdidae, and two species of flycatcher, plus published data for European Robin an Pied Flycatcher, which are from the Muscicapidae (see Table 1 for details of the species and sample sizes). Nests were constructed by wild birds and were collected by BTO nest recorders who, to maintain the nests structural integrity and composition, removed the nests carefully from in situ. Nests were collected from a wide range of locations across the United Kingdom after the known end of the breeding season following BTO guidelines (Biddle et al., 2017). To reduce the chance of damage during transportation to the University of Lincoln, nests were posted in well packaged cardboard boxes. On arrival at the University of Lincoln, each nest was dried before being placed into a plastic bag within a cardboard box and stored at room temperature and humidity until analysed, which ranged from approximately 3-24 months after collection.

\subsection{Nest characteristics}

Nests were elliptical in shape so the diameter of the overall nest and cup was measured parallel and perpendicular to the long axis of the cup (Bocheński, 1968; Biddle et al., 2016, 2017). Digital callipers (Mitutoyo, Absolute Digimatic) were used to measure nest and cup diameters, nest height and cup depth. Wall thickness was measured at four points around the nest (Biddle et al., 2016). Electronic scales (A and D Company Limited, model FX3000i, Sartorius, model Entris 3202i-1S) were used to measure the weight of each nest and its corresponding parts 
after deconstruction. The volume of the nest cups was determined by first lining the cup with domestic cling film before $5 \mathrm{~mm}$ diameter solid glass beads (Sigma-Aldrich) were added until the cup was filled to the top edge (Biddle et al., 2015). The weight of the beads was then used to determine the volume of each cup based on a predetermined density (g/ $\mathrm{cm}^{3}$, Biddle et al., 2015). Dimensions were available for all nests except for those 25 nests from the report by Briggs and Deeming (2016) for the Pied Flycatcher, which did not record this information.

\subsection{Nest deconstruction}

Nests were first visually examined to identify any distinct regions before being deconstructed. Finch nests consisted of two easily identifiable regions: the outer nest and the inner cup lining. Most Song Thrush (Turdus philomelos) nests were also comprised of only two distinct regions (Bocheński, 1968): the outer nest and an inner composite cup of dried wood pulp resembling papier mâché and a cup lining being absent within all but two nests. The three remaining thrush nests, Common Blackbird, Ring Ouzel (Turdus torquatus) and Mistle Thrush (Turdus viscivorus), were all composed of three distinct regions (Bocheński, 1968; Ryves, 1928): an outer nest, a mudcomposite cup and an internal cup lining.

After all morphometric measurements had been recorded nest deconstruction was carefully carried out using forceps to reduce damage to the materials (Britt and Deeming, 2011; Biddle et al., 2015, 2017). Nests were separated into three or four sections depending on species. These were: cup lining, cup, upper outer side nest (material around the sides of the cup), and outer nest base (material below the base of the cup). In thrush nests the mud composite cup structure was defined as the cup and typically within this was a cup lining, a distinct layer considered to have no significant structural role (Hansell, 2000). The external layer of the nests was defined as the outer nest (including any possible decorative layer) and was distinctly different to the mud cup and cup lining. The outer nest and the mud cup made up the structural wall of thrush nests. Finch and flycatcher nests were also composed of an external outer nest/ structural region and an internal cup-shaped cup lining.

Firstly, for thrush nests when present, the cup lining was extracted from within the cup. All nests were inverted to allow the base of the outer nest to be detached. The outer nest material present around the side of the cup was then removed leaving just the cup in thrushes and cup lining in finches. Deconstruction of Bullfinch nests followed the methodology of Biddle et al. (2017), which first removed the top of the outer nest until the lower limit of the outer part of the cup was reached, the cup lining was then removed leaving the base of the outer nest. Once nests were divided into different regions the individual components (described in Table 2) were separated to determine the quantity of materials present. Although Biddle et al. (2017) separated woody and herbaceous stems of Bullfinch nests, these were combined during this study. The number of different types of materials used in the whole nest, just the outer nest, and just the cup were also counted.

\subsection{Statistical analysis}

Paired t-tests were first carried out to determine if wall thickness varied between the different orientations measured (parallel and perpendicular to the long axis of the cup). Twelve species showed no significant difference in wall thickness. The average wall thickness parallel and perpendicular to the cup was significantly different for Goldfinch nests (paired t-test: $t_{9}=4.78, \mathrm{p}=0.001$ ). However, as this was the only species a mean wall thickness was calculated for all species. 
The mean value for each measurement of the fourteen species was calculated. Spearman's rank correlation was used to determine whether mean female body mass derived from the literature (Cramp, 1988; Cramp and Perrins, 1994) correlated with the mean nest measurements.

A generalised linear mixed model was used in Minitab (version 17) to determine whether there were differences between the different parts of the nest across family. The model included nest-ID and species as random factors, and with nest-ID nested within species, which was nested within family to control for data from the same nest.

Principal component analysis weights the data based on the different composition components included in the analysis, and allowed investigation of whether nest composition could be separated by different species and family. Principal component analysis (PCA) was carried out in Minitab (Version 17) on the total composition of each nest in order to compare the composition of the fourteen different species. The first three principal components were then used to distinguish the composition of nests for the species. Levene's tests were carried out on each of the three principal components to determine if the variance was homogeneous between the species or family. Furthermore, Kruskal-Wallis tests were used to determine if the principal components were affected by species or by family.

To compare the composition of the outer nest and the cup lining, each material was converted to a proportion of the relevant part of the nest before ASIN-transformation (to help normalise the distribution; Fowler et al., 1998). A stepwise discriminant analysis (IBM SPSS Statistics 21) was carried out to compare these proportions (Britt and Deeming, 2011). The significance level was set at an F-value of 3.84 (i.e., P < 0.05), which is the default for the test.

\section{RESULTS}

\subsection{Nest dimensions}

European Goldfinches (Cardueulis carduelis) and Hawfinches (Coccothraustes coccothraustes) are the smallest and largest birds of the finches, respectively, represented in this study (Table 1). However, while the Goldfinch nests had the smallest measurements for most dimensions, the largest dimensions recorded were not always for Hawfinch nests. The nests of Hawfinches had the largest cup and total nest diameters but European Greenfinch (Chloris chloris) nests were taller with greatest cup depths and volume. Other species had intermediate nest dimensions. Nests of Stonechats (Saxicola torquatus) and European Robins were comparable in mass and most dimensions but those of Whinchats (Saxicola rubreta) were smaller despite having the largest mean body mass (Table 1). For most thrush nest dimensions, the smallest recorded measurements were for the Song Thrush and the largest measurements were for the Mistle Thrush (Table 1). Thrushes constructed nests with thinner upper wall thickness relative to base thickness (ratio averaged around 0.63) but in flycatchers the wall to base ratio averaged 0.83. Finches constructed nests with slightly thicker walls such that the wall to base ratio averaged 0.89 .

Significant positive correlations were observed between the female body mass, volume and most of the dimensions of the nests (Table 1). Only nest wall thickness and base thickness failed to show any correlation with female body mass.

\subsection{General descriptions}


The types and quantities of materials used to construct nests varied between the fourteen species studied are reported here as masses (Tables 3, 4 and 5), and as percentage values of the total nest (Figure 1). Animal-derived materials consisted of arthropod silk but this weighs very little and was only found in finch nests. Feathers and hair were more common but again were largely confined to finch nests (Table 3, Figure 1). Plant-derived materials were more varied with moss, stems, grass, roots, and lichen being relatively common components of both finch and thrush nests (Table 3, Figure 1). Mineral materials were almost exclusively found in thrush nests and formed between $20-77 \%$ of the nest mass in three species. The cup structure in Song Thrushes was made of dried wood pulp that resembled papier mâché. Manmade materials were relatively uncommon but found more frequently in finch nests (Figure 1).

The Goldfinch constructed the lightest of the nests investigated here (Table 1). Generally, the nests were constructed of an outer nest composed largely of moss (23\%) and stems (25\%; Figure 2A), and an internal cup lining composed largely of hair (35\%) as well as feathers (12\%) and plant/seed fibres (12\%; Figure 3A). By contrast, Linnet nests were constructed of two regions; an outer nest composed largely of grass (65\%; Figure 2A) and a cup lining composed largely of hair (39\%; Figure 3A). Chaffinch nests were constructed of an internal cup lining composed largely of hair (45\%) and feathers (24\%; Figure 3A). An external outer nest was composed largely of moss (approximately 40\%) and lichen (16\%), found largely on the external surface of the nest (Figure 2A). Greenfinch nests were the heaviest (Table 1), with two distinct regions: an external outer nest composed largely of moss (46\%; Figure 2A) and an internal cup lining composed of hair (25\%) and feathers (14\%; Figure 3A).

Bullfinch nests were composed of an internal cup lining constructed of roots (59\%) and thin grass culms (16\%; Figure 3A) with an outer structural layer composed of stems (89\%; Figure 2A). Similar to Bullfinch nests, Hawfinch nests were also composed of an outer nest of stems (88\%; Figure 2A) and an internal lining composed of roots (41\%) and, in particular, lichen (50\%; Figure 3A).

Flycatcher nests were of a comparable size to some of the larger finch nests (Table 1) with Whinchats producing the lightest nests despite being the heaviest of the three species. Grasses, moss, leaves, hair and feathers are relatively common in chat nests (Figure 1B). Both outer nests and cups were comprised of similar materials with grass predominating in most species (10-45\% of the outer nest and 30-65\% of the cup lining; Figures $2 \mathrm{~B}$ and 3B).

Blackbird nests were the heaviest of the nests studied here and were constructed of three distinct regions. An outer nest composed largely of grass (22\%), moss (21\%) and stems (16\%; Figure 2C). Within this a mud/mineral cup lined primarily with grass (43\%; Figure 3C). Ring Ouzel nests had an internal cup lining of grass (48\%; Figure 3C), a mud cup and then an outer region composed of moss (13\%), grass (18\%) and stems (19\%; Figure 2C). The outer nest also contained fern shoots, which was largely absent in the other thrush nests. Mistle thrush nests were constructed an outer nest dominated by moss (23\%), grass (12\%), and stems (20\%) but also a high proportion of lichen (20\%; Figure 2C). A mud cup and cup lining composed largely of grass (43\%; Figure 3C) were also present. Song thrush nests were constructed of two distinct regions. An outer region composed of grass (33\%), moss (21\%) and stems (19\%; Figure 2C) surrounding a distinct cup. This cup appeared to be composed of wood pulp and completely lacked any additional lining, with the exception of two nests, in which the cup lining was composed largely of leaves (56\%; Figure 3C). 
Sixteen different material types were found across the species although not all were used by every species or in each nest (Figure 4). Generally, the outer nest had a higher number of material categories than in the cup lining. The Bullfinch and Hawfinch were different in this respect because the outer nest had the fewest number of materials (Figure 4). A general linear mixed model showed that the number of materials in each nest part (i.e., outer nest and cup lining) was significantly affected by the part of the nest concerned $\left(\mathrm{F}_{1,153}=24.88, \mathrm{P}<0.001\right)$ but not by family as an individual factor $\left(\mathrm{F}_{2,153}=1.29, \mathrm{P}=0.316\right)$ but there was a significant interaction $\left(\mathrm{F}_{2,153}=\right.$ 3.69, $\mathrm{P}=0.027)$. Nest-ID and species were also significant random factors $\left(\mathrm{F}_{135,153}=1.68, \mathrm{P}=0.001, \mathrm{~F}_{10,153}=\right.$ 24.89, $\mathrm{P}<0.001$, respectively) and $\mathrm{R}^{2}$ for the model was $83.0 \%$.

\subsection{Species and family comparisons}

Following principal component analysis for all nest components for all species, PC1, PC2 and PC3 explained 13.6\%, $10.9 \%$ and $10.1 \%$ of the variance, respectively (Table 6). Loadings for PC1 reflected a measure of 'softness' with large negative values being associated with “soft” animal-derived materials, such as feathers and moss (Table 6). By contrast, the larger positive values were associated with the harder stems and mineral material (Table 6). The loadings for PC2 (Table 6) separated the materials based on whether they were hair and lichen (large negative values) or leaves and bark (large positive values). By contrast, for PC3 the loadings indicated large negative values were also associated with more heather and fern, whereas large positive values were associated with wood pulp (Table 6).

Such characteristics allowed the separation of species when PC1 and PC2 were plotted against each other (Figure 5A). Most finches grouped together (negative PC1 scores and positive PC2 scores; Figure 5A), although Bullfinch and Hawfinch nests were characterised by their high stem content the other finch species contained very little stem or mineral material. Linnet nests were characterised by more fibrous materials, i.e. grass (identified by PC3) and softer materials (high positive values for PC1) characterised Greenfinch, Goldfinch, and Chaffinch nests. For PC1 there was little difference between the four species of flycatcher but for PC2 Pied Flycatchers and Robins were more similar to each other with more positive values (more leaves and bark) than the two chat species, which were more characterised by grass and roots (Figure 5A). The thrush species generally grouped together in the positive values for PC1, which were generally associated with their mineralised cup structures, but were more variable in PC2 (Figure 5A).

None of the first three PC values were normally distributed and Levene's test showed that the variances in PC1, PC2 and PC3 were not homogeneous between species (Table 6). Kruskal-Wallis tests showed that median values for PC1, PC2 and PC3 were highly significantly affected by species (Table 6). In general, most variation in nest composition was seen in the Ring Ouzel, Mistle Thrush, Greenfinch and Chaffinch.

Levene's tests for the effect of family showed significant lack of homogeneity for PC1, PC2 and PC3 (12.97, 6.74, 11.06, P < 0.01 in all cases, respectively). Kruskal-Wallis tests showed highly significant effects of family ( $\mathrm{H}=120.67,54.09 \& 64.43, \mathrm{P}<0.001$, respectively).

The cup found within thrush nests was largely composed of a mineral-plant material composite, or wood pulp in the Song Thrush. However, to determine if this was the cause of the clustering of the thrush nests and the separation from the finch nests, principal component analysis was repeated without the mineral and wood pulp components. Within this test PC1, PC2 and PC3 explained similar amount of the variation to the complete nests (Table 6). The loadings for PC1 (Figure 5B) continued to reflect a measure of 'softness' (large negative values 
being associated with animal-derived materials and large positive values associated with harder plant derived materials, stems and roots). Loadings for PC2 (Figure 5B) separated plant derived materials into hair and lichen (large negative values) and bark and leaves (large positive values). In PC3 large negative values were associated with lichen and stem, while large positive values were associated with fern and heather (Table 6). The thrush nests still remained grouped (Figure 5B) but were more similar to Hawfinch and Bullfinch nests. The other finches and the chats plotted in similar parts of the graph but Robins and Pied Flycatchers were characterised more by more leaves and bark in PC2 (Figure 5B).

Levene's test showed that the variance in PC1, PC2 and PC3 were not homogenous between species (Table 6). Kruskal-Wallis tests showed that median values for PC1, PC2 and PC3 were highly significantly affected by species (Table 6). As before, greatest variation in nest composition was shown by the Ring Ouzel, Mistle Thrush, Greenfinch and Chaffinch. Levene's tests for the effect of family showed significant lack of homogeneity for PC1, PC2 and PC3 ( $F=12.13,5.24,10.02, \mathrm{P}<0.001$ in all cases, respectively). Kruskal-Wallis tests showed highly significant effects of family ( $\mathrm{H}=76.70,58.11 \& 49.02, \mathrm{P}<0.001$, respectively).

\subsection{Comparison of cup lining and outer nest}

The distribution of the various materials between the cup lining and the outer nest varied between species. Grass, moss, and stems were most commonly found in the outer nest (Figure 2) but only grass was found in any great quantities in the cup lining, particularly in thrush nests (Figure 3). By contrast, particularly in finch nests, feathers and hair formed high proportions of the cup lining (Figure 3) but were relatively rare in the outer nest (Figure 2). Manmade materials were mainly found in the cup lining.

The nests of the finch species were composed of two distinct regions, which varied in composition. The largest finches, Hawfinches and Bullfinches, had nests composed of an outer nest of stems (Figure 2), while the remaining finches had an outer nest composed of a greater number of materials. The outer nest of Linnets was composed largely of grass and although grass was present in Chaffinch, Goldfinch and Greenfinch, moss made up a larger proportion of the nest mass. The cup lining of Hawfinch and Bullfinch nests was composed largely of roots together with lichen in Hawfinch and grass in Bullfinch nests. The cup lining composition of the other four finch species was composed largely of hair and feathers.

Discriminate analysis showed that in Bullfinch and Hawfinch nests stems were the only distinguishing component between the cup lining and the outer nest, with a greater amount present in the outer nest (Table 7). The greater proportion of stems and moss found in the outer nest of the Goldfinch, and the greater amount of feathers and hair present in the cup lining of the Chaffinch and Greenfinch nests, respectively, allows discrimination between the different nest regions. Furthermore, it was possible to distinguish the parts of Linnet nests using roots, which were greater in the outer nest, and hair, which was greater in the cup. The amounts and types of materials used in Chaffinch nests were very variable yet the cup and outer nest could be discriminated by several types of materials in this species (Table 7).

The cup lining of Stonechat nests had significantly less moss than the outer nest and Robins had more grass in the cup (Table 7). Whinchats incorporated more roots in the outer nest and more grass and hair in the cup (Table 7). Pied Flycatcher nests had significantly more fern, leaves and moss in the outer nest but more roots in the cup (Table 7). 
Thrush nests were composed of three distinct regions. Going from the external to the internal surface of each nest there was first an outer nest, which was largely composed of moss, grass and stems. Within the outer nest was a 'mud/mineral' cup which consists of materials cemented together to form a solid bowl like structure which has outer nest materials adhering to its outer surface. This appeared to be composed of a mud composite in Blackbird, Mistle Thrush and Ring Ouzel nests. By contrast in Song Thrush nests this structure resembled papier mâché, being composed of more woody material. The 'mud' cup was a characteristic structure in all four thrush nests and making up a large proportion of a nests overall weight (20-77\%). No comparable structure was observed in any finch or flycatcher nest. The third distinct internal region was the cup lining, composed largely of grass, present in Blackbirds, Mistle thrush and Ring Ouzel nests. Only two Song Thrush nests had an internal lining composed largely of leaves whereas the other nests were empty of any lining materials.

Discriminant analysis (Table 7) showed that there was a significantly greater proportion of moss and stems present in the outer nest of Blackbird nests than the cup lining. The greater proportion of grass within the cup lining of Ring Ouzel nests, as well as the greater proportions of bark, hair and moss present in the outer nest of Ring Ouzel nests discriminated the two distinct regions. The outer nest of Mistle thrushes could be distinguished using feathers, lichen, moss, and stems, all of which made up a larger proportion of the outer nest compared the cup lining. Mineral content was also greater in the outer nest of Blackbirds, Mistle Thrushes and Song Thrushes.

\section{DISCUSSION}

In general, nest weight and dimensions significantly correlated with female body mass with the exception of wall thickness and base thickness. It was also possible to distinguish between species and family on the basis of their nest composition. Thrush nests were generally similar to each other in composition but were different to nests constructed by flycatchers, which were in turn different from finch nests. There was some overlap between some finch nests and those of chats. The degree of intraspecific variation was not uniform with some species exhibiting little variation in composition and other being more variable. For each species it was possible to distinguish between the different part of the nest using at least one key material used in each region.

\subsection{Nest Dimensions}

It is known that larger bird species build larger nests compared to smaller bird species (Slagsvold, 1989a; Hansell, 2000; Heenan and Seymour, 2011; Deeming, 2013) and as predicted this was observed for the different species of nests analysed within this study, with larger thrushes constructing bigger nests than the smaller flycatchers and finches. Although the base of the nest is thicker in the nests of most species within this study the larger thrushes built nests with the greatest thickness difference. This may reflect need for greater support from below due to the greater weight of the bird and chicks. However, the base and wall thickness of Bullfinch and Hawfinch nests were similar in thickness, so this may reflect the composition or structural properties of the outer nest (Biddle et al., 2017) or perhaps the structural characteristics of the branches the nests were built on.

Nest dimensions recorded for the finch species were comparable to those previously described by Biddle et al. (2016) as well as the majority of dimensions recorded in Cramp and Perrins (1994). Nest dimensions recorded for Linnets were also like those described previously (Von Dietmar, 1996; Gray and Deeming, 2017), although the inner nest diameter was slightly larger in this study. Chaffinch nest measurements were comparable to those reported by Slagsvold (1989b) except nests were shorter in height. Bullfinch measurements were 
comparable to those reported by Bocheński and Oles (1981) although the total weight of the nest and the cup were slightly lower than previously reported (Doerbeck, 1963). Hawfinch nests had smaller nest height and outer nest diameters than those reported by Mountfort (1957). Flycatcher nests were similar to previous reports (Cramp, 1988) although this is the first report of nest dimensions for the Whinchat. The nest dimensions recorded for each of the four thrush species are comparable to those previously described (Bocheński, 1968; Cramp, 1988; Janiga and Višňovská, 2004; Biddle et al., 2015, 2016).

The species studied here differed in their degree of variability in nest size. For instance, the Hawfinch exhibited greater variability in nest mass than other finches with chaffinches being most uniform in mass. Mistle Thrushes constructed nests of greater variable mass whereas Ring Ouzels were more uniform. Such plasticity in nest construction seems to be the norm in any species of bird so far studied but it is not always clear why this should be so (Walsh et al., 2010, 2011; Deeming and Mainwaring, 2015). Nest dimensions can show intraspecific variation for a number of reasons. These include differences in latitude with nests constructed at cooler higher latitudes being thicker and heavier (Rohwer and Law, 2010; Crossman et al., 2011; Mainwaring et al., 2012, 2014b). Also, nests constructed closer to the ground are also are larger (Wysocki et al., 2015). The functional aspects of this nest variability have yet to be fully explored but may reflect the mechanical, thermal and/or hydrological properties of the nest as a whole or its component parts. Mechanical properties of materials have been studied for Blackbird and Bullfinch nests (Biddle et al., 2015, 2017) but further research is needed to better understand how nest size relates to its functions.

\subsection{Nest Composition}

Although general description of the nests investigated in this study are available (for example in Harrison, 1975, 1978; Ferguson-Lees et al., 2011), the data for the mass of materials used in the nests are only available for Blackbirds (Mainwaring et al., 2014b). The composition of finch nests recorded within this study are comparable to previous reports (Newton, 1972; Cramp and Perrins, 1994; Ferguson-Lees et al., 2011) for each of the six species, although some differences were observed. The Hawfinch nests deconstructed within this study contained little grass which was described as being present within the cups of most nests (Mountfort, 1957; Newton, 1972; Cramp and Perrins, 1994). Bullfinch nests were also similar to previous reports (Nicolai, 1956; Bocheński and Oles, 1981; Newton, 1993) but not all nests analysed contained hair, which contradicts Ferguson-Lees et al. (2011) who suggested that all Bullfinch nests were lined with hair. Linnet nests within this study were composed of a large quantity of grass, which was not reported by Cramp and Perrins (1994) although the composition was comparable to Gray and Deeming (2017), Von Dietmar (1996) and proportions of the materials reported by Slagsvold (1989b), except for the proportion of roots.

The composition of thrush nests was also comparable to previous reports (Bocheński, 1968; Simms, 1978; Cramp, 1988; Mainwaring et al., 2014b). The mud cup of Blackbird, Ring Ouzel and Mistle Thrush nests was composed of a mud composite including natural materials, such as grass, leaves and other vegetative fragments and it was often incomplete (as reported by Bocheński, 1968). By contrast, the papier mâché cup of Song Thrush nests generally lacked holes. It was generally made of wood pulp but other materials, e.g. mud, vegetable parts, animal dung and cigarette butts, have been reported (Bocheński, 1968; Igic et al., 2009). This difference in composition may account for the lower weight of the cup found in the nests of the Song Thrush, the exact composition of which is worthy of further investigation. 
For flycatchers, chat nests were of comparable composition, and the Robin and Pied Flycatcher were also similar but different from that built by the chats. Variation between these two pairs was mainly reflected in the amount of leaves and bark, and grass and roots in PC2 rather than in the variables more favoured by PC1. The Pied Flycatcher nests reported here were from Lancashire, UK (Briggs and Deeming, 2016) and were different from those reported from Wales or Spain (Moreno et al., 2008; Deeming and Mainwaring, 2015). Common Redstarts (Phoenicurus phoenicurus) also differ from other Muscicapidae nests in being constructed of manly grasses and feathers (see Deeming and Mainwaring, 2015).

Qualitative descriptions of nest compositions are made for a wide range of species (for example in Ferguson-Lees et al., 2011). However, quantitative data is only available for a few species (Deeming and Mainwaring, 2015) and data presented here significantly contribute to the dataset for nest composition. This is the first study to quantitatively demonstrate that it is generally possible to distinguish between the nests of different species based on composition. Principal component analysis (PCA) also showed that the different species had variable nest composition, and species from different families tended to cluster together. However, the first three PC-scores explained only 35\% of the variation which suggests that results of this PCA would have little importance in assessing functional differences of nests. Indeed, such analyses are more likely to rely on the data for actual composition of each nest.

Although there is a degree of plasticity in nest construction, as indicated by intraspecific variability in this study and others (Britt and Deeming, 2011; Briggs and Deeming, 2016), there is also a degree of species specificity with regard to the materials used. This suggests that composition of nests may reflect particular characteristics of nest sites chosen by a species and a variety of materials may reflect different solutions to the same problem. For instance, lining a nest cup for insulation or perhaps softness may be achieved using a variety of materials.

As well as being different from each other, the composition of the nests within this study are also different from the thrush and finches studied from nest sites in Canada (Crossman et al., 2011). Crossman et al. (2011) reported that the nests of the American Robin (Turdus migratorius) were composed largely of dirt and fine materials, contrasting thrushes within this study that were largely composed of mud, grass, moss, and woody materials. American Goldfinches (Carduelis tristis) and Common Redpolls (Carduelis flammea) were also composed of different materials to the six finches within this study as well as different percentages from each other. American Goldfinches were composed largely of grass and soft plant material, while Common Redpolls were composed largely of grass, sticks and soft plant materials. This further suggests that although the composition of nests varies due to a range of factors the different species of birds appear to be selecting different materials needed for nest construction. Future research could seek to compare the nest composition of other European members of the families within this study, such as the Wheater (Oenanthe oenanthe), the Fieldfare (Turdus pilaris) and Redwing (Turdus iliacus) of the Turdidae or the Siskin (Spinus spinus) and Twite (Linaria flavirostris) of the Fringillidae, in order to further compare the variety of nests.

\subsection{Variability in nest construction}

Although nests appear similar within species the construction of nests is a plastic behaviour with individual birds constructing nests in different ways (Walsh et al., 2011), which may reflect individual preferences or relate to biotic or abiotic factors. Species effects in use of materials were apparent with the number of types of materials 
used in a nest (and its component parts) being species-specific. Why Hawfinch, Bullfinch and Robin nests used the fewest types of materials is unclear but may reflect nest location or the particular characteristics of the materials used.

Climate can affect nest construction with temperature changes with latitude significantly affecting nest construction (Rohwer and Law, 2010; Crossman et al., 2011; Mainwaring et al., 2012, 2014b). Nests constructed at latitudes with warmer temperatures had smaller nests with decreased external diameters and wall thicknesses. However, Britt and Deeming (2011) and Deeming et al. (2012) suggested the nest mass was affected by the temperature experienced seven days preceding clutch initiation irrespective of latitude because nests built later in the year that are smaller in cup depth, wall width and nest height (Powell and Rangen, 2000). However, Wysocki et al. (2015) found no relationship between temperature and the size of the nest constructed in Blackbirds. In the Hummingbirds (Sephanoides sephaniodes) and (Oreotrochilus leucopleurus) there was a positive relationship between precipitation and the number of nesting materials used during nest construction (Calvelo et al., 2006).

Other factors that affect nest size and composition include the time taken to construct the nest (Wysocki et al., 2015). Smaller Blackbird nests have been shown to be constructed faster due to the reduction in the number of trips needed to collect nesting material (Wysocki et al., 2015). Smaller Blackbird nests are also constructed at greater heights above ground as well as by more inexperienced females (Wysocki et al. 2015). Nest attempt number (Powell and Rangen, 2000) and bird health may play a role as well. Mainwaring et al. (2008) found a positive relationship in Blue Tits between nest weight and feather mite load, while Tomás et al. (2006) found heavier nests to be constructed by females not infected with Trypanosoma avium. Heavier nests are built by birds that have experienced supplemental feeding during nest construction (Mainwaring and Hartley, 2009; Smith et al., 2013). This is due to the time-consuming and energetically expensive behaviour of nest building being limited by food availability (Mainwaring and Hartley, 2009; Smith et al., 2013).

Manmade materials, e.g. string, coir (suspected to be from commercially available hanging baskets), thin strips of plastic and artificial hair, present within the nests studied here made up a small proportion of the overall nest weight and were largely found within the cup lining of finches. It is assumed that the materials used by the species studied here use anthropogenic materials for their resemblance to natural materials, e.g. string and coir resemble fibrous roots and grass, rather than for any specific property. By contrast, Chinese Bulbul (Pycnonotus sinensis) and House Sparrow (Passer domesticus) nests constructed in urban areas have greater proportions of anthropogenic materials, such as plastic and cloth, with a decrease in the usage of plant matter (Wang et al., 2009; Radhamany et al. 2016). Hanmer et al. (2017) reported that across urban and rural habitats Great Tits used anthropogenic materials for over 25\% of their nest materials but Blue Tits used 1-2\%. The use of this manmade materials inversely correlated with ectoparasite loads. By contrast, Reynolds et al. (2016) found anthropogenic material did not differ in their contribution to the overall nest composition along an urban gradient for Blue tit nests. Anthropogenic materials may play other roles. Cigarette butts incorporated into nests are associated with lower ectoparasite loads (Suárez-Rodríguez et al., 2013) and white plastic incorporated into Black Kite (Milvus migrans) nests is interpreted as being a phenotypic signal to conspecifics about fitness (Sergio et al., 2011).

Construction materials chosen may also vary depending on the materials which would provide the best camouflage (Bailey et al., 2015), or because of a material's structural properties. Blackbirds and Bullfinches build nests with significantly thicker, stronger, and more rigid material in the outer nest (Biddle et al., 2015, 2017). Male Cape Weavers (Ploceus capensis) selected a limited number of plant species and long, stronger materials to 
build their nests (Bailey et al., 2016). The experience of the bird may also influence the materials chosen during nest construction, as in in captive Zebra Finches (Taeniopygia guttata; Muth and Healy 2011, Bailey et al. 2014). Furthermore, Bailey et al. (2016) proposed that male Zebra Finches in territories of a more 'desirable' location flew further to collect materials than those that weren't due to the benefits gained from holding that territory. However, reports do suggest that birds are opportunistic in their use of materials because they are more likely to select materials present within the local environment (Moreno et al., 2008; Surgey et al., 2012; Álvarez et al., 2013; Cantarero et al., 2015; Briggs and Deeming, 2016).

\subsection{Separation of nest regions}

Hansell (2000) described nests as being constructed of four different regions, attachment, outer (decorative layer), structural layer and lining. Each of the fourteen species of nest within this study were constructed of a structural wall and a lining (absent in Song Thrush nests). The structural wall in thrush nests consisted of an outer nest and the mineral cup enclosing the cup lining. In flycatcher and finch nests the structural wall was only composed of the outer nest and within this a cup shaped lining. In all species it was possible to distinguish between nest parts with the cup lining typically being composed of softer, more pliable materials than the surrounding outer nest. This suggests that during nest construction birds bring differing types of materials in a non-random manner that may only be appropriate for a particular location within the structure.

Detailed descriptions of nest construction behaviour are relatively rare (Healy et al., 2015) but whilst recording the construction of American Robin nests Howell (1943) observed a change in behaviour as nest construction proceeded by bringing different materials at progressive stages. This species is closely related to the European thrushes, therefore it is possible that the selection of materials for the species within this study is not random. The distribution of different materials in different parts of the nest suggests some behavioural selection by the bird (Biddle et al., 2017). Hilton et al. (2004) demonstrated that hair and feathers provide good thermal insulation, therefore its position largely in the cup lining may be due to the thermal insulation it would provide to the eggs/chicks needed in the nests of smaller species. The presence of roots and grass within the cup lining of Bullfinch, Hawfinch and thrush nests may not provide as greater thermal insulation as hair and feathers but may still provide a softer lining than woody stems. The varying compositions of the outer nest may also play a different role in the nest such as support and camouflage.

Although nest size and composition can vary due to a range of factors it is still possible to distinguish the nests of some species. This may reflect particular nesting locations. Ring Ouzel nests are constructed largely on moorlands (Ferguson-Lees et al., 2011) so it may be coincidental that they contain more moorland plants, such as heather and ferns (Simms, 1978), which were largely absent from the nests of the other three species of thrush. However, other parts of nests may reflect particular aspects of the structure. Mud cups were restricted to thrushes and this structure may reflect a means by which these heavier birds and their clutches can be supported during incubation and rearing (Biddle et al., 2015). The nests dominated by leaves and moss built by Pied Flycatchers and Robins may reflect the fact that they are generally cavity nesters in woodland. By contrast, the chats nest in more open, heath-like habitats use different types of plants in their nests. Whether these other materials have a structural role is as yet unclear. A nest made purely of plant stems, characteristic of larger finches, may not provide sufficient support for the heavier birds and it would be interesting to study other "twig” nests built by larger birds, e.g. corvids or pigeons (Ferguson-Lees et al. 2015). 


\section{CONCLUSION}

This report significantly adds to the data available for the composition of bird nests and shows that materials used can be specific to species and the part of the nest. There is a need for more research into the composition of nests of a wider range of other species to ascertain whether the Turdidae, Muscicapidae and Fringillidae are generally representative of passerine nests. Most importantly there is a need to better understand nest construction behaviour in a range of birds to allow insight into the criteria used by individuals when choosing and placing materials in a nest. These may affect the thermal or hydrological properties of the nests. Although deconstruction provides insight into the nest's component parts the real challenge is to understand the functionality of these parts when they are combined into a composite structure.

\section{ACKNOWLEDGEMENTS}

We thank the numerous members of the BTO nest record scheme who generously supplied the nests used in this study. Lucia Biddle is grateful for the financial support of the School of Life sciences, University of Lincoln.

\section{REFERENCES}

Álvarez, E., Belda, E.J., Verdejo, J. and Barba, E. (2013) Variation in Great Tit nest mass and composition and its breeding consequences: a comparative study in four Mediterranean habitats. Avian Biol. Res., 6, 3946.

Bailey, I.E., Morgan, K.V., Bertin, M., Meddle, S.L. and Healy, S.D. (2014) Physical cognition: birds learn the structural efficacy of nest material. Proc. R. Soc. B, 281, 20133225.

Bailey, I.E., Muth, F., Morgan, K.V., Meddle, S.L. and Healy, S.D. (2015) Birds build camouflaged nests. Auk, 132, 11-15.

Bailey, I.E., Morgan, K.V., Oschadleus H.D., DeRuiter, S.L., Meddle, S.L. and Healy, S.D. (2016) Nestbuilding males trade off material collection costs with territory value. Emu, 116, 1-8.

Biddle, L.E., Deeming, D.C. and Goodman, A.W. (2015) Morphology and biomechanics of the nests of the Common Blackbird Turdus merula. Bird Study, 62, 87-95.

Biddle, L.E., Goodman, A.M. and Deeming, D.C. (2016) Geographical effects on the mass and dimensions of finch (Fringillidae, Passeriformes) and thrush (Turdidae, Passeriformes) nests. Avian Biol. Res., 9, 1321.

Biddle, L.E., Goodman, A.M. and Deeming, D.C. (2017) Construction patterns of birds' nests provide insight into nest-building behaviours. Peer J, 5, e3010.

Bocheński, Z. (1968) Nesting of the European members of the genus Turdus Linnaeus 1758 (Aves). Acta Zool. Cracoviensia, 13, 349-439.

Bocheński, Z. and Oles, T. (1981) Experimental studies on the nesting of Bullfinch Pyrrhula pyrrhula (Linnaeus, 1758) in aviaries. Acta Zool. Cracoviensia, 25, 3-12.

Briggs, K.B. and Deeming, D.C. (2016) Use of materials in nest construction by Pied Flycatchers Ficedula hypoleuca reflects localised habitat and geographical location. Bird Study, 63, 516-524. 
Britt, J. and Deeming, D.C. (2011) First egg date and air temperature affect nest construction in Blue Tits Cyanistes caeruleus but not in Great Tits Parus major. Bird Study, 58, 78-89.

Calvelo, S., Trejo, A. and Ojeda, V. (2006) Botanical composition and structure of hummingbird nests in different habitats from north-western Patagonia (Argentina). J. Nat. Hist., 40, 589-603.

Cantarero, A., López-Arrabé, J. and Moreno, J. (2015) Selection of nest site and nesting material in the Eurasian Nuthatch Sitta europaea. Ardea, 103, 91-94.

Collias, N.E. and Collias, E.C. (1984) Nest building and bird behaviour. Princeton University Press, Princeton.

Cramp, S. (1988) Handbook of the Birds of Europe, the Middle East and North Africa. The Birds of the Western Palearctic, vol. V Tyrant flycatcher to thrushes. Oxford: Oxford University Press, Oxford.

Cramp, S. and Perrins, C.M. (1994) Handbook of the Birds of Europe, the Middle East and North Africa. The Birds of the Western Palearctic, vol. VIII crows to finches. Oxford University Press, Oxford.

Crossman, C.A., Rohwer, V.G. and Martin, P.R. (2011) Variation in the structure of bird nests between northern Manitoba and southeastern Ontario. PLoS ONE, 6, e19086.

Deeming, D.C. (2013) Effects of female body size and phylogeny in avian nest dimensions. Avian Biol. Res., 6, 1-11.

Deeming, D.C. (2016) How does the bird-nest incubation unit work? Avian Biol. Res., 9, 103-113.

Deeming, D.C. and Mainwaring, M.C. (2015) Functional Properties of Nests. In: Nest, Eggs, and Incubation: New Ideas Avian Reproduction Deeming, D.C. and Reynolds, S.J. (eds), pp. 29-49. Oxford University Press, Oxford.

Deeming, D.C., Mainwaring, M.C., Hartley, I.R. and Reynolds, S.J. (2012) Local temperature and not latitude determines the design of Blue Tit and Great Tit nests. Avian Biol. Res., 5, 203-208.

Doerbeck, F. (1963) Zur Biologie der Gimpels Pyrrhula pyrrhula in der Grossstadt. Die Vogel., 84, 97-114.

Dubiec, A., Góźdź, I. and Mazgajski, T.D. (2013) Green plant material in avian nests. Avian Biol. Res., 6, 133146.

Ferguson-Lees, J., Castell, R. and Leech, D. (2011) A field guide to monitoring nests. British Trust for Ornithology, Thetford.

Fowler, J., Cohen, J.L. and Jarvis, P. (1998) Practical statistics for field biology. Second edition. Wiley, Chichester, UK.

Gray, L.A. and Deeming, D.C. (2017) Effect of air movement on the thermal insulation of avian nests. Bird Study, doi: 10.1080/00063657.2017.1387518

Hanmer, H.J., Thomas, R.L., Beswick, G.J.F., Collins, B.P. and Fellowes, M.D.E. (2017) Use of anthropogenic material affects bird nest arthropod community structure: influence of urbanisation, and consequences for ectoparasites and fledging success. J. Ornithol., 158, 1049-1059.

Hansell, M.H. (2000) Bird nests and construction behaviour. Cambridge: Cambridge University Press.

Harrison, C.J.O. (1975) A field guide to the nests, eggs and nestlings of European birds, with North Africa and the Middle East. London: Collins.

Harrison, C.J.O. (1978) A field guide to the nests, eggs and nestings of North American birds. Collins, New York. Healy, S.D., Morgan, K.V and Bailey, I.E. (2015) Nest construction behaviour. In Nest, Eggs, and Incubation: New Ideas Avian Reproduction Deeming, D.C. and Reynolds, S.J. (eds), pp. 16-28. Oxford University Press, Oxford. 
Heenan, C.B. and Seymour, R.S. (2011) Structural support, not insulation, is the primary driver for avian cupshaped nest design. Proc. R. Soc. B, 278, 2924-2929.

Hilton, G.M., Hansell, M.H., Ruxton, G.D., Reid, J.M. and Monaghan, P. (2004) Using artificial nests to test importance of nesting material and nest shelter for incubation energetics. Auk, 121, 777-787.

Howell, J.C. (1943) Notes on the nesting habits of the American robin (Turdus migratorius L.). Amer. Midl. Nat., 28, 529-603.

Igic, B., Cassey, P., Samas, P., Grim, T. and Hauber, M.E. (2009) Cigarette butts form a perceptually cryptic component of Song thrush (Turdus philomelos) nests. Notornis, 56, 134-138.

Janiga, M. and Višňovská, Z. (2004) The placement and the size and shape of Ring Ouzel (Turdus torquatus) reflect the environmental conditions at different altitude. Oecologia, 13, 11-16.

Kern, M.D. (1984) Racial differences in nests of White-crowned sparrows. Condor, 86, 455-466.

Kern, M.C. and Van Riper, C. (1984) Altitudinal variations in nests of the Hawaiian Honeycreeper Hemignathus virens virens. Condor, 86, 443-454.

Mainwaring, M.C. (2015) The use of man-made structures as nesting sites by birds: A review of the costs and benefits. J. Nat. Cons. 25: 17-22

Mainwaring M.C. and Hartley, I.R. (2008). Seasonal adjustments in nest cup lining in Blue Tits Cyanistes caeruleus. Ardea, 96, 278-282.

Mainwaring, M.C. and Hartley, I.R. (2009) Experimental evidence for state-dependent nest weight in the blue tit, Cyanistes caeruleus. Behav. Proc., 81, 144-146.

Mainwaring, M.C., Hartley, I.R., Bearhop, S., Brulez, K., du Feu, C.R., Murphy, G., Plummer, K., Webber, S.L., Reynold, S.J. and Deeming, D.C. (2012) Latitudinal variation in blue and great tit nests characteristics indicates environments adjustment. J. Biogeogr., 39, 1669-1677.

Mainwaring, M.C., Hartley, I.R., Lambrechts, M.M. and Deeming, D.C. (2014a) The design and function of birds’ nests. Ecol. Evol., 4, 3909-3928.

Mainwaring, M.C., Deeming, D.C., Jones, C.I. and Hartley, I.R. (2014b) Adaptive latitudinal variation in Common Blackbirds Turdus merula nest characteristics. Ecol. Evol., 4, 841-851.

Malzer, I. and Hansell, M. (2017) Nest timing, nest site selection and nest structure in a high latitude population of Bearded Reedlings Panurus biarmicus. Bird Study, 64, 51-61.

Moreno, J. (2012) Avian nests and nest building as signals. Avian Biol. Res., 5, 238-251.

Moreno, J., Martínez, J., Corral, C., Lobato, E., Merino, S., Morales, J., Martínez-de la Puente, J. and Tomás, G. (2008) Nest construction rate and stress in female Pied Flycatchers Ficedula hypoleuca. Acta Ornithol., 43, 57-64.

Mountford, G. (1957) The Hawfinch. Collins, London.

Muth, F. and Healy, S.D. (2011) The role of adult experience in the nest building zebra finch. Anim. Behav., 82, 185-189.

Newton, I. (1972) Finches. Collins, London.

Newton, I. (1993) Studies of West Palearctic birds 192. Bullfinch. Brit. Birds, 86, 638-648.

Nicolai, J. (1956) Zur Biologie und Ethologie des Gimpels (Pyrrhula pyrrhula, L.). Ethology, 13, 93-132.

Ontiveros, D., Carom J. and Pleguezuelos, J.M. (2008) Green plant material versus ectoparasites in nests of Bonelli’s eagle. J. Zool., 274, 99-104. 
Powell, L.A. and Rangen, K.L. (2000) Variation in wood thrush nest dimensions and construction. North Amer. Bird Bander, 25, 89-96.

Radhamany, D., Sakthidas Anoop Das, K., Abdul Azeez, P., Wen, L. and Sreekala, K.L. (2016) Usage of Nest Materials by House Sparrow (Passer domesticus) Along an Urban to Rural Gradient in Coimbatore, India. Trop. Life Sci. Res., 27, 127-134.

Reynolds, S.J., Davies, C.S., Elwell, E., Tasker, P.J., Williams, A., Sadler, J.P. and Hunt, D. (2016) Does the urban gradient influence the composition and ectoparasite load of nests of an urban bird species? Avian Biol. Res. 9: 224-234.

Rohwer, V.G. and Law, J.S.Y. (2010) Geographical variation in nests of yellow warblers breeding in Churchill, Manitoba, and Elgin, Ontario. Condor, 112, 596-604.

Ryves, B.H. (1928) Some breeding habits of the mistle thrush in Cornwall. Brit. Birds, 22, 31-33.

Sergio, F., Blas, J., Blanco, G., Tanferna, A., López, L., Lemus, J.A. and Hiraldo, F. (2011) Raptor nest decorations are a reliable threat against conspecifics. Science, 331, 327-330.

Simms, E. (1978) British Thrushes. Harper Collins, London.

Slagsvold, T. (1989a) On the evolution of clutch size and nest size in passerine birds. Oecologia 79, 300-305.

Slagsvold, T. (1989b) Experiments on clutch size and nest size in passerine birds. Oecologia, 80, $297-302$.

Smith, J.A., Harrison, T.J.E., Martin, G.R. and Reynolds, S.J. (2013) Feathering the nest: food supplementation influences nest construction by Blue (Cyanistes caeruleus) and Great Tits (Parus major). Avian Biol. Res., 6, 18-25.

Suárez-Rodríguez, M., López-Rull, I., and Garcia, C.M. (2013) Incorporation of cigarette butts into nests reduces nest ectoparasite load in urban birds: new ingredients for an old recipe? Biol. Lett., 9, 20120931.

Surgey, J., du Feu, C.R. and Deeming D.C. (2012) Opportunistic use of a wool-like artificial material as lining of tit (Paridae) nests. Condor, 114, 385-392.

Taberner Cerezo, A. and Deeming, D.C. (2016) Nest insulation in the European Robin (Erithacus rubecula): Effects of latitude and construction materials. Avian Biol. Res., 9, 96-102.

Tomás, G., Merino, S., Martinez-de la Puente, J., Moreno, J., Morales, J. and, Rivero-de Aguilar, J. (2013) Nest size and aromatic plants in the nest as sexually selected female traits in blue tits. Behav. Ecol., 24, 926934.

Tomás, G., Merino, S., Sanz, J.J., Morales, J. and García-Fraile, S. (2006) Nest weight and female health in the blue tit (Cyanistes caeruleus). Auk, 123, 1013-1021.

Von Dietmar, W. (1996) Zur Brutbiologie einer alpinen Population des Bluthänflings Carduelis cannabina aim Allgäu /Bayern. Ornithol. Anz., 35, 84-90.

Walsh, P.T., Hansell, M., Borello, W.D. and, Healy, S.D. (2010) Repeatability of nest morphology in African weaver birds. Biol. Lett., 6, 149-151.

Walsh, P.T., Hansell, M., Borello, W.D. and, Healy, S.D. (2011) Individuality in nest building: Do Southern Masked weaver (Ploceus velatus) males vary in their nest-building behaviour? Behav. Proc., 88, 1-6.

Wang, Y., Chen, S., Blair, R.B., Jiang, P. and Ding, P. (2009) Nest composition adjustments by Chinese Bulbuls Pycnonotus sinensis in an urbanized landscape of Hangzhou (E China). Acta Ornithol., 44, 185-192.

Wysocki, D., Jankowiak, Ł., Greño, J. L., Cichocka, A., Sondej, I. and Michalska, B. (2015) Factors affecting nest size in a population of Blackbirds Turdus merula. Bird Study, 62, 208-216. 
Figure 1 - Composition of nests constructed by (A) six species of finch (Fringillidae), (B) four species of flycatcher (Muscicapidae), and (C) four species of thrush (Turdidae). Values are mean ( \pm SE) values of the different materials expressed as a percentage of the total nest weight.

Figure 2 - Composition of nests constructed by (A) six species of finch (Fringillidae), (B) four species of flycatcher (Muscicapidae), and (C) four species of thrush (Turdidae). Values are mean ( \pm SE) values of the different materials expressed as a percentage of the outer nest weight. Note that For thrush nests the outer nest does not include the mineralised structural cup.

Figure 3 - Composition of nests constructed by (A) six species of finch (Fringillidae), (B) four species of flycatcher (Muscicapidae), and (C) four species of thrush (Turdidae). Values are mean ( \pm SE) values of the different materials expressed as a percentage of the cup lining weight. Note only two Song Thrush nests contained a cup lining.

Figure 4 - Mean (+SE) number of categories of materials found in the total nest (Blue), outer nest (orange) and cup lining (grey) for the fourteen species of nests.

Figure 5 - Mean $( \pm$ SE) values for PC1 and PC2 values the fourteen species of birds when (A) all components or (B) all components with wood pulp and mineral excluded in the principal component analysis. The interpretation of the PC scores is as indicated by the arrows parallel to the axis. Circles indicate members of the Fringillidae, triangles indicates members of the Muscicapidae, and squares indicate members of the Turdidae. 
Table 2 - Description of materials allocated the categories used during nest deconstruction.

\begin{tabular}{|l|l|}
\hline Material & Defined as \\
\hline Arthropod silk & Silk created from an arthropod such as a spider \\
\hline Feather & Any feathers irrespective type or species \\
\hline Hair & Animal-derived fibres including wool and horse hair \\
\hline Bark & The outer covering of woody materials \\
\hline Fern & The stems of fern plants \\
\hline Grass & Any grass materials, including stems and leaves \\
\hline Heather & Stems from the heather shrub. \\
\hline Leaves & Blades and petioles of a leaf \\
\hline Lichen & Any lichen species \\
\hline Moss & Any moss species \\
\hline Plant fibres & Natural plant-based fibres from an unknown source. \\
\hline Roots & Any roots from a range of grass, herbaceous and woody eudicot species. \\
\hline Stems & Any woody and herbaceous stems. \\
\hline Wood pulp & Dried wood pulp resembling papier mâché \\
\hline Mineral & Any mud and stones \\
\hline Manmade & $\begin{array}{l}\text { Any artificial material of manmade origin, including string, plastic and coir } \\
\text { apparently from commercially available hanging basket liners. }\end{array}$ \\
\hline
\end{tabular}




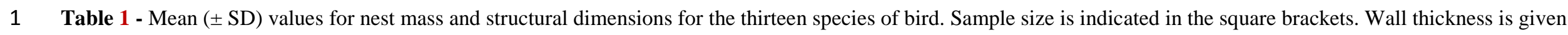
2 as the mean of all four sides. Spearman's rho values are at the bottom of each column for the correlation between the mean nest dimension with mean female body mass

3 (Data from Cramp, 1988: Cramp and Perrins, 1994). Dimensions data were unavailable for the 25 Pied Flycatcher (Ficedula hypoleuca) nests.

\begin{tabular}{|c|c|c|c|c|c|c|c|c|c|c|c|}
\hline & $\begin{array}{c}\text { Female } \\
\text { Body } \\
\text { Mass (g) }\end{array}$ & $\begin{array}{l}\text { Total mass } \\
\text { of nest (g) }\end{array}$ & $\begin{array}{l}\text { Cup diameter } \\
\text { parallel to } \\
\text { long axis } \\
\text { (mm) }\end{array}$ & $\begin{array}{l}\text { Cup diameter } \\
\text { perpendicular } \\
\text { to long axis } \\
(\mathrm{mm})\end{array}$ & $\begin{array}{l}\text { Nest diameter } \\
\text { parallel to } \\
\text { long axis } \\
\text { (mm) }\end{array}$ & $\begin{array}{l}\text { Nest diameter } \\
\text { perpendicular } \\
\text { to long axis } \\
(\mathrm{mm})\end{array}$ & $\begin{array}{l}\text { Upper wall } \\
\text { thickness } \\
(\mathrm{mm})\end{array}$ & $\begin{array}{c}\text { Base } \\
\text { Thickness } \\
(\mathrm{mm})\end{array}$ & $\begin{array}{l}\text { Cup depth } \\
\text { (mm) }\end{array}$ & $\begin{array}{l}\text { Nest Height } \\
\text { (mm) }\end{array}$ & Volume $\left(\mathrm{cm}^{3}\right)$ \\
\hline \multicolumn{12}{|l|}{ Fringillidae } \\
\hline $\begin{array}{l}\text { European Goldfinch } \\
\text { (Carduelis Carduelis) [10] }\end{array}$ & 16.4 & $8.3 \pm 2.4$ & $62.8 \pm 12.1$ & $54.8 \pm 7.4$ & $91.4 \pm 9.3$ & $77.8 \pm 7.9$ & $12.8 \pm 3.3$ & $15.7 \pm 4.3$ & $26.0 \pm 5.5$ & $41.6 \pm 7.4$ & $38.0 \pm 9.1$ \\
\hline $\begin{array}{l}\text { Common Linnet } \\
\text { (Linaria cannabina) [11] }\end{array}$ & 18.0 & $18.9 \pm 5.4$ & $74.7 \pm 6.3$ & $59.9 \pm 8.6$ & $107.9 \pm 8.8$ & $95.1 \pm 10.2$ & $16.9 \pm 4.9$ & $24.5 \pm 8.9$ & $30.6 \pm 9.8$ & $55.1 \pm 9.2$ & $60.9 \pm 20.8$ \\
\hline $\begin{array}{l}\text { Common Chaffinch } \\
\text { (Fringilla coelebs) [11] }\end{array}$ & 21.5 & $14.5 \pm 2.9$ & $63.3 \pm 8.1$ & $50.8 \pm 8.0$ & $98.7 \pm 10.9$ & $90.3 \pm 9.8$ & $18.5 \pm 3.6$ & $23.6 \pm 7.6$ & $34.3 \pm 7.8$ & $58.0 \pm 7.3$ & $58.3 \pm 15.0$ \\
\hline $\begin{array}{l}\text { European Greenfinch } \\
\text { (Chloris chloris) [5] }\end{array}$ & 25.9 & $22.4 \pm 6.2$ & $75.6 \pm 7.8$ & $53.9 \pm 11.8$ & $128.6 \pm 13.7$ & $99.7 \pm 16.2$ & $24.9 \pm 7.9$ & $29.4 \pm 6.0$ & $35.4 \pm 5.7$ & $64.9 \pm 9.4$ & $74.5 \pm 12.2$ \\
\hline $\begin{array}{l}\text { Eurasian Bullfinch } \\
\text { (Pyrrhula pyrrhula) [17] }\end{array}$ & 27.3 & $12.1 \pm 4.6$ & $80.8 \pm 12.1$ & $66.4 \pm 8.1$ & $129.7 \pm 23.4$ & $117.5 \pm 19.6$ & $24.8 \pm 10.9$ & $24.2 \pm 10.7$ & $22.6 \pm 4.5$ & $46.8 \pm 11.3$ & $45.0 \pm 3.8$ \\
\hline $\begin{array}{l}\text { Hawfinch (Coccothraustes } \\
\text { coccothraustes) [4] }\end{array}$ & 52.9 & $27.4 \pm 7.3$ & $102.2 \pm 17.9$ & $78.8 \pm 25.2$ & $153.4 \pm 19.1$ & $131.3 \pm 27.1$ & $25.4 \pm 5.9$ & $23.3 \pm 4.9$ & $31.4 \pm 10.9$ & $54.7 \pm 11.5$ & $71.6 \pm 12.9$ \\
\hline \multicolumn{12}{|l|}{ Muscicapidae } \\
\hline $\begin{array}{l}\text { Stonechat } \\
\text { (Saxicola torquatus) [9] }\end{array}$ & 14.0 & $28.0 \pm 11.4$ & $84.2 \pm 32.8$ & $68.6 \pm 21.3$ & $115.7 \pm 35.3$ & $102.6 \pm 29.8$ & $30.2 \pm 7.3$ & $35.8 \pm 17.7$ & $30.5 \pm 6.9$ & $66.1 \pm 19.7$ & $91.0 \pm 46.5$ \\
\hline $\begin{array}{l}\text { European Robin } \\
\text { (Erithula rubecula) [12] }\end{array}$ & 16.5 & $28.8 \pm 10.8$ & $74.0 \pm 16.7$ & $57.0 \pm 10.8$ & $146.6 \pm 23.5$ & $127.8 \pm 20.2$ & $27.3 \pm 10.0$ & $29.2 \pm 10.8$ & $29.0 \pm 10.0$ & $59.0 \pm 14.0$ & $68.4 \pm 29.8$ \\
\hline $\begin{array}{l}\text { Whinchat } \\
\text { (Saxicola rubreta) [8] }\end{array}$ & 16.7 & $17.8 \pm 6.2$ & $78.4 \pm 13.4$ & $59.1 \pm 15.0$ & $133.7 \pm 17.8$ & $111.0 \pm 13.2$ & $26.4 \pm 4.0$ & $35.6 \pm 8.2$ & $15.9 \pm 4.5$ & $51.5 \pm 9.7$ & $51.9 \pm 27.4$ \\
\hline \multicolumn{12}{|l|}{ Turdidae } \\
\hline $\begin{array}{l}\text { Song Thrush } \\
\text { (Turdus philomelos) [26] }\end{array}$ & 71 & $92.6 \pm 38.7$ & $99.9 \pm 7.7$ & $85.4 \pm 8.3$ & $147.9 \pm 20.6$ & $130.7 \pm 10.1$ & $20.2 \pm 2.8$ & $34.4 \pm 17.4$ & $59.8 \pm 7.6$ & $94.1 \pm 17.9$ & $288.9 \pm 55.9$ \\
\hline
\end{tabular}




\begin{tabular}{|c|c|c|c|c|c|c|c|c|c|c|c|}
\hline $\begin{array}{l}\text { Common Blackbird } \\
\text { (Turdus merula) [20] }\end{array}$ & 99.8 & $\begin{array}{c}180.4 \pm \\
56.8\end{array}$ & $112.3 \pm 7.9$ & $95.0 \pm 7.9$ & $151.5 \pm 13.1$ & $135.8 \pm 12.8$ & $19.3 \pm 5.1$ & $35.6 \pm 11.7$ & $59.1 \pm 8.8$ & $94.7 \pm 13.3$ & $293.6 \pm 78.5$ \\
\hline $\begin{array}{l}\text { Ring Ouzel } \\
\text { (Turdus torquatus) [9] }\end{array}$ & 106 & $\begin{array}{c}160.4 \pm \\
35.6\end{array}$ & $112.7 \pm 7.6$ & $99.1 \pm 13.2$ & $168.8 \pm 21.8$ & $155.2 \pm 17.6$ & $28.7 \pm 9.0$ & $40.0 \pm 14.1$ & $59.2 \pm 11.9$ & $98.7 \pm 14.6$ & $298.6 \pm 125.1$ \\
\hline $\begin{array}{l}\text { Mistle Thrush } \\
\text { (Turdus viscivorus) [11] }\end{array}$ & 131.3 & $\begin{array}{c}176.2 \pm \\
81.6\end{array}$ & $117.4 \pm 8.9$ & $92.6 \pm 10.9$ & $170.8 \pm 20.3$ & $162.0 \pm 22.3$ & $30.5 \pm 8.0$ & $45.0 \pm 19.0$ & $53.7 \pm 6.2$ & $98.7 \pm 22.7$ & $266.1 \pm 56.6$ \\
\hline Spearman rho (p-value) & & $\begin{array}{c}0.610 \\
(0.027)\end{array}$ & $\begin{array}{c}0.786 \\
(0.001)\end{array}$ & $\begin{array}{c}0.698 \\
(0.008)\end{array}$ & $\begin{array}{c}0.786 \\
(0.001)\end{array}$ & $\begin{array}{c}0.725 \\
(0.005)\end{array}$ & $\begin{array}{c}0.192 \\
(0.592)\end{array}$ & $\begin{array}{c}0.393 \\
(0.184)\end{array}$ & $\begin{array}{c}0.742 \\
(0.004)\end{array}$ & $\begin{array}{c}0.602 \\
(0.029)\end{array}$ & $\begin{array}{c}0.637 \\
(0.019)\end{array}$ \\
\hline
\end{tabular}


7 Table 3 - Mean mass (g, \pm SD) of the category of material present within each region for each species of finch (Fringillidae). Dash indicates that the material 8 was not present. Wood pulp was absent from all nests. 9

\begin{tabular}{|c|c|c|c|c|c|c|c|}
\hline & & Eurasian Bullfinch & Common Chaffinch & European Goldfinch & $\begin{array}{l}\text { European } \\
\text { Greenfinch }\end{array}$ & Hawfinch & Common Linnet \\
\hline \multirow[t]{3}{*}{ Arthropod Silk } & Total nest & - & $0.086 \pm 0.127$ & $0.012 \pm 0.035$ & $0.004 \pm 0.009$ & - & $0.003 \pm 0.009$ \\
\hline & Outer nest & - & $0.085 \pm 0.127$ & $0.012 \pm 0.035$ & $0.004 \pm 0.009$ & - & $0.002 \pm 0.006$ \\
\hline & Cup lining & - & $0.001 \pm 0.003$ & - & & - & $0.001 \pm 0.003$ \\
\hline \multirow[t]{3}{*}{ Feather } & Total nest & $0.000 \pm 0.000$ & $1.397 \pm 1.046$ & $0.495 \pm 0.651$ & $1.088 \pm 0.706$ & - & $0.176 \pm 0.265$ \\
\hline & Outer nest & $0.000 \pm 0.000$ & $0.068 \pm 0.075$ & $0.046 \pm 0.083$ & $0.128 \pm 0.186$ & - & $0.016 \pm 0.037$ \\
\hline & Cup lining & $0.000 \pm 0.000$ & $1.329 \pm 0.987$ & $0.449 \pm 0.583$ & $0.960 \pm 0.537$ & - & $0.160 \pm 0.246$ \\
\hline \multirow[t]{3}{*}{ Hair } & Total nest & $0.181 \pm 0.349$ & $2.742 \pm 1.839$ & $1.496 \pm 0.887$ & $2.422 \pm 3.104$ & $0.018 \pm 0.035$ & $2.696 \pm 1.594$ \\
\hline & Outer nest & $0.001 \pm 0.003$ & $0.555 \pm 0.481$ & $0.482 \pm 0.477$ & $0.380 \pm 0.594$ & $0.000 \pm 0.000$ & $0.203 \pm 0.192$ \\
\hline & Cup lining & $0.180 \pm 0.348$ & $2.186 \pm 1.647$ & $1.014 \pm 0.621$ & $2.042 \pm 2.546$ & $0.018 \pm 0.035$ & $2.489 \pm 1.531$ \\
\hline \multirow[t]{3}{*}{ Bark } & Total nest & $0.006 \pm 0.020$ & $0.196 \pm 0.345$ & - & $0.226 \pm 0.326$ & $0.015 \pm 0.013$ & $0.000 \pm 0.000$ \\
\hline & Outer nest & $0.005 \pm 0.019$ & $0.122 \pm 0.205$ & - & $0.178 \pm 0.261$ & $0.000 \pm 0.000$ & - \\
\hline & Cup lining & $0.001 \pm 0.005$ & $0.074 \pm 0.215$ & - & $0.032 \pm 0.072$ & $0.013 \pm 0.015$ & $0.000 \pm 0.000$ \\
\hline \multirow[t]{3}{*}{ Fern } & Total nest & - & - & - & - & - & $0.021 \pm 0.055$ \\
\hline & Outer nest & - & - & - & - & - & $0.021 \pm 0.055$ \\
\hline & Cup lining & - & - & - & - & - & - \\
\hline \multirow[t]{3}{*}{ Grass } & Total nest & $0.721 \pm 0.632$ & $1.127 \pm 1.308$ & $0.134 \pm 0.219$ & $0.710 \pm 0.425$ & $0.008 \pm 0.015$ & $8.846 \pm 3.555$ \\
\hline & Outer nest & $0.271 \pm 0.294$ & $0.840 \pm 1.179$ & $0.110 \pm 0.183$ & $0.512 \pm 0.423$ & - & $7.554 \pm 2.975$ \\
\hline & Cup lining & $0.445 \pm 0.481$ & $0.287 \pm 0.270$ & $0.021 \pm 0.050$ & $0.176 \pm 0.162$ & $0.008 \pm 0.015$ & $0.843 \pm 0.677$ \\
\hline \multirow[t]{3}{*}{ Heather } & Total nest & - & $0.089 \pm 0.273$ & $0.013 \pm 0.041$ & - & - & $0.009 \pm 0.021$ \\
\hline & Outer nest & - & $0.089 \pm 0.273$ & $0.013 \pm 0.041$ & - & - & $0.009 \pm 0.021$ \\
\hline & Cup lining & - & - & - & - & - & $0.000 \pm 0.000$ \\
\hline \multirow[t]{3}{*}{ Leaves } & Total nest & $0.074 \pm 0.128$ & $0.130 \pm 0.314$ & $0.099 \pm 0.136$ & $0.780 \pm 1.599$ & $0.053 \pm 0.064$ & $0.033 \pm 0.059$ \\
\hline & Outer nest & $0.041 \pm 0.083$ & $0.116 \pm 0.297$ & $0.084 \pm 0.129$ & $0.226 \pm 0.388$ & $0.003 \pm 0.005$ & $0.011 \pm 0.019$ \\
\hline & Cup lining & $0.027 \pm 0.071$ & $0.007 \pm 0.017$ & $0.003 \pm 0.010$ & $0.552 \pm 1.207$ & $0.008 \pm 0.010$ & $0.000 \pm 0.000$ \\
\hline
\end{tabular}




\begin{tabular}{|c|c|c|c|c|c|c|c|}
\hline \multirow[t]{3}{*}{ Lichen } & Total nest & - & $1.628 \pm 1.026$ & $0.618 \pm 0.918$ & $0.062 \pm 0.118$ & $5.385 \pm 1.619$ & $0.001 \pm 0.003$ \\
\hline & Outer nest & - & $1.422 \pm 0.858$ & $0.553 \pm 0.812$ & $0.040 \pm 0.069$ & $1.453 \pm 1.536$ & - \\
\hline & Cup lining & - & $0.194 \pm 0.250$ & $0.065 \pm 0.143$ & $0.022 \pm 0.049$ & $3.168 \pm 1.540$ & - \\
\hline \multirow[t]{3}{*}{ Moss } & Total nest & $0.052 \pm 0.080$ & $3.886 \pm 1.221$ & $1.309 \pm 1.030$ & $7.570 \pm 4.873$ & $0.000 \pm 0.000$ & $1.130 \pm 1.149$ \\
\hline & Outer nest & $0.024 \pm 0.057$ & $3.406 \pm 1.243$ & $1.193 \pm 0.996$ & $6.836 \pm 4.708$ & - & $0.736 \pm 0.779$ \\
\hline & Cup lining & $0.029 \pm 0.033$ & $0.480 \pm 0.500$ & $0.116 \pm 0.081$ & $0.700 \pm 0.396$ & $0.000 \pm 0.000$ & $0.385 \pm 0.452$ \\
\hline \multirow[t]{3}{*}{ Plant/Seed Fibres } & Total nest & - & $0.115 \pm 0.256$ & $0.332 \pm 0.438$ & $0.636 \pm 0.785$ & - & $0.346 \pm 0.792$ \\
\hline & Outer nest & - & $0.042 \pm 0.135$ & $0.026 \pm 0.055$ & $0.054 \pm 0.074$ & - & $0.179 \pm 0.594$ \\
\hline & Cup lining & - & $0.073 \pm 0.199$ & $0.306 \pm 0.401$ & $0.582 \pm 0.722$ & - & $0.166 \pm 0.446$ \\
\hline \multirow[t]{3}{*}{ Roots } & Total nest & $2.410 \pm 1.151$ & $0.095 \pm 0.129$ & $0.353 \pm 0.407$ & $1.544 \pm 1.602$ & $3.640 \pm 1.996$ & $0.998 \pm 1.066$ \\
\hline & Outer nest & $0.501 \pm 0.535$ & $0.043 \pm 0.062$ & $0.314 \pm 0.401$ & $0.934 \pm 1.627$ & $0.725 \pm 0.778$ & $0.825 \pm 0.949$ \\
\hline & Cup lining & $1.900 \pm 1.152$ & $0.052 \pm 0.075$ & $0.039 \pm 0.038$ & $0.600 \pm 0.776$ & $2.670 \pm 1.569$ & $0.167 \pm 0.182$ \\
\hline \multirow[t]{3}{*}{ Stems } & Total nest & $9.673 \pm 4.582$ & $1.318 \pm 1.433$ & $1.339 \pm 0.583$ & $2.444 \pm 1.046$ & $18.135 \pm 5.132$ & $1.836 \pm 2.112$ \\
\hline & Outer nest & $9.143 \pm 4.724$ & $1.244 \pm 1.434$ & $1.220 \pm 0.543$ & $2.036 \pm 0.917$ & $15.285 \pm 4.085$ & $1.310 \pm 1.858$ \\
\hline & Cup lining & $0.279 \pm 0.312$ & $0.016 \pm 0.023$ & $0.051 \pm 0.059$ & $0.166 \pm 0.197$ & $0.415 \pm 0.131$ & $0.120 \pm 0.118$ \\
\hline \multirow[t]{3}{*}{ Mineral } & Total nest & $0.002 \pm 0.007$ & - & $0.008 \pm 0.025$ & $1.846 \pm 2.006$ & $0.008 \pm 0.015$ & $0.183 \pm 0.208$ \\
\hline & Outer nest & - & - & $0.008 \pm 0.025$ & $1.438 \pm 1.625$ & - & $0.106 \pm 0.168$ \\
\hline & Cup lining & $0.002 \pm 0.007$ & - & - & $0.300 \pm 0.352$ & $0.008 \pm 0.015$ & $0.070 \pm 0.075$ \\
\hline \multirow[t]{3}{*}{ Manmade } & Total nest & $0.062 \pm 0.222$ & $0.135 \pm 0.265$ & $0.269 \pm 0.443$ & $0.048 \pm 0.061$ & $0.000 \pm 0.000$ & $0.430 \pm 0.931$ \\
\hline & Outer nest & $0.000 \pm 0.000$ & $0.037 \pm 0.070$ & $0.086 \pm 0.155$ & $0.006 \pm 0.013$ & - & $0.047 \pm 0.102$ \\
\hline & Cup lining & $0.062 \pm 0.222$ & $0.097 \pm 0.200$ & $0.183 \pm 0.308$ & $0.042 \pm 0.059$ & $0.000 \pm 0.000$ & $0.383 \pm 0.852$ \\
\hline
\end{tabular}

10

11 
Table 4 - Mean mass (g, \pm SD) of the category of material present within each region for each species of Old World flycatcher (Muscicapidae). Dash indicates that the material was not present in the nest. Heather and Wood pulp were absent from all nests.

\begin{tabular}{|c|c|c|c|c|c|}
\hline & & Stonechat & Whinchat & European Robin* & Pied Flycatcher** \\
\hline \multirow{3}{*}{$\begin{array}{l}\text { Arthropod } \\
\text { Silk }\end{array}$} & Total nest & - & - & - & - \\
\hline & Outer nest & - & - & - & - \\
\hline & Cup lining & - & - & - & - \\
\hline \multirow{3}{*}{ Feather } & Total nest & $0.777 \pm 0.884$ & $0.005 \pm 0.014$ & - & $0.001 \pm 0.005$ \\
\hline & Outer nest & $0.588 \pm 0.697$ & $0.003 \pm 0.007$ & - & $0.00 \pm 0.005$ \\
\hline & Cup lining & $0.189 \pm 0.272$ & $0.003 \pm 0.007$ & - & - \\
\hline \multirow{3}{*}{ Hair } & Total nest & $4.019 \pm 2.603$ & $0.231 \pm 0.920$ & $0.182 \pm 0.462$ & $0.141 \pm 0.305$ \\
\hline & Outer nest & $3.192 \pm 2.080$ & $0.494 \pm 0.402$ & $0.026 \pm 0.053$ & $0.100 \pm 0.270$ \\
\hline & Cup lining & $0.827 \pm 0.993$ & $0.738 \pm 0.758$ & $0.156 \pm 0.433$ & $0.082 \pm 0.230$ \\
\hline \multirow{3}{*}{ Bark } & Total nest & - & - & $0.228 \pm 0.791$ & $2.674 \pm 2.025$ \\
\hline & Outer nest & - & - & $0.141 \pm 0.488$ & $1.232 \pm 0.335$ \\
\hline & Cup lining & - & - & $0.088 \pm 0.303$ & $1.326 \pm 1.060$ \\
\hline \multirow{3}{*}{ Fern } & Total nest & - & - & - & $0.309 \pm 0.400$ \\
\hline & Outer nest & - & - & - & $0.252 \pm 0.335$ \\
\hline & Cup lining & - & - & - & $0.049 \pm 0.125$ \\
\hline \multirow{3}{*}{ Grass } & Total nest & $13.070 \pm 9.190$ & $9.704 \pm 2.736$ & $3.183 \pm 3.347$ & $2.190 \pm 1.185$ \\
\hline & Outer nest & $5.950 \pm 4.710$ & $6.378 \pm 2.295$ & $2.171 \pm 3.067$ & $1.267 \pm 0.750$ \\
\hline & Cup lining & $7.120 \pm 4.710$ & $3.326 \pm 1.616$ & $1.013 \pm 0.728$ & $1.007 \pm 0.735$ \\
\hline \multirow{3}{*}{ Leaves } & Total nest & $0.311 \pm 0.411$ & $1.356 \pm 1.529$ & $9.260 \pm 6.640$ & $7.147 \pm 4.070$ \\
\hline & Outer nest & $0.087 \pm 0.124$ & $1.129 \pm 1.287$ & $8.400 \pm 5.990$ & $5.176 \pm 3.385$ \\
\hline & Cup lining & $0.224 \pm 0.329$ & $0.228 \pm 0.270$ & $0.861 \pm 0.982$ & $1.846 \pm 1.100$ \\
\hline \multirow{3}{*}{ Lichen } & Total nest & $0.017 \pm 0.046$ & $0.605 \pm 1.130$ & - & $0.008 \pm 0.030$ \\
\hline & Outer nest & $0.002 \pm 0.004$ & $0.599 \pm 1.115$ & - & $0.006 \pm 0.030$ \\
\hline & Cup lining & $0.014 \pm 0.043$ & $0.006 \pm 0.018$ & - & $0.003 \pm 0.015$ \\
\hline \multirow{3}{*}{ Moss } & Total nest & $9.360 \pm 3.93$ & $0.448 \pm 1.515$ & $8.300 \pm 6.480$ & $7.541 \pm 4.475$ \\
\hline & Outer nest & $2.364 \pm 0.627$ & $3.298 \pm 1.491$ & $8.040 \pm 5.980$ & $7.032 \pm 6.433$ \\
\hline & Cup lining & $6.998 \pm 0.859$ & $0.448 \pm 0.230$ & $0.926 \pm 0.927$ & $0.620 \pm 0.785$ \\
\hline \multirow{3}{*}{$\begin{array}{l}\text { Plant } \\
\text { Fibres }\end{array}$} & Total nest & - & - & $0.461 \pm 1.172$ & - \\
\hline & Outer nest & - & - & $0.248 \pm 0.625$ & - \\
\hline & Cup lining & - & - & $0.213 \pm 0.584$ & - \\
\hline \multirow{3}{*}{ Roots } & Total nest & $0.006 \pm 0.017$ & $0.076 \pm 0.104$ & $0.215 \pm 0.696$ & $0.435 \pm 0.550$ \\
\hline & Outer nest & $0.006 \pm 0.017$ & $0.061 \pm 0.093$ & $0.097 \pm 0.335$ & $0.134 \pm 0.135$ \\
\hline & Cup lining & $0.000 \pm 0.000$ & $0.015 \pm 0.026$ & $0.118 \pm 0.362$ & $0.346 \pm 0.445$ \\
\hline \multirow{3}{*}{ Stems } & Total nest & $0.403 \pm 0.308$ & $1.098 \pm 0.691$ & $1.393 \pm 1.686$ & $0.124 \pm 0.290$ \\
\hline & Outer nest & $0.048 \pm 0.018$ & $0.990 \pm 0.623$ & $1.181 \pm 1.636$ & $0.106 \pm 0.265$ \\
\hline & Cup lining & $0.356 \pm 0.101$ & $1.098 \pm 0.128$ & $0.212 \pm 0.399$ & $0.006 \pm 0.030$ \\
\hline \multirow{2}{*}{ Mineral } & Total nest & - & - & $0.413 \pm 1.215$ & - \\
\hline & Outer nest & - & - & $0.351 \pm 1.215$ & - \\
\hline
\end{tabular}




\begin{tabular}{|c|c|c|c|c|c|}
\hline & Cup lining & - & - & $0.062 \pm 0.214$ & - \\
\hline \multirow{4}{*}{ Manmade } & Total nest & $0.628 \pm 1.190$ & - & - & $0.007 \pm 0.018$ \\
\cline { 2 - 6 } & Outer nest & $0.149 \pm 0.226$ & - & - & $0.004 \pm 0.015$ \\
\cline { 2 - 6 } & Cup lining & $0.479 \pm 1.029$ & - & - & $0.001 \pm 0.005$ \\
\hline
\end{tabular}

*Data from Taberner Cerezo and Deeming (2016); **Data from Briggs and Deeming (2016) 
Table 5 - Mean mass (g, \pm SD) of the category of material present within each region for each species of thrush (Turdidae). Dash indicates that the material was not present in the nest. Arthropod silk was absent from all nests

\begin{tabular}{|c|c|c|c|c|c|}
\hline & & $\begin{array}{l}\text { Common } \\
\text { Blackbird }\end{array}$ & Mistle Thrush & Ring Ouzel & Song Thrush** \\
\hline \multirow{3}{*}{ Feather } & Total nest & $0.394 \pm 1.589$ & $0.102 \pm 0.217$ & $0.104 \pm 0.201$ & $0.012 \pm 0.036$ \\
\hline & Outer nest & $0.345 \pm 1.428$ & $0.085 \pm 0.194$ & $0.026 \pm 0.045$ & $0.012 \pm 0.036$ \\
\hline & Cup lining & $0.006 \pm 0.025$ & $0.016 \pm 0.027$ & $0.076 \pm 0.205$ & - \\
\hline \multirow{3}{*}{ Hair } & Total nest & $0.015 \pm 0.034$ & $1.406 \pm 1.453$ & $0.333 \pm 0.978$ & $0.012 \pm 0.053$ \\
\hline & Outer nest & $0.008 \pm 0.026$ & $1.234 \pm 1.336$ & $0.322 \pm 0.967$ & $0.012 \pm 0.053$ \\
\hline & Cup lining & $0.006 \pm 0.018$ & $0.173 \pm 0.302$ & $0.011 \pm 0.020$ & - \\
\hline \multirow{3}{*}{ Bark } & Total nest & $1.038 \pm 2.968$ & $0.267 \pm 0.555$ & $0.083 \pm 0.129$ & $0.017 \pm 0.069$ \\
\hline & Outer nest & $0.990 \pm 2.948$ & $0.262 \pm 0.558$ & $0.036 \pm 0.045$ & $0.017 \pm 0.069$ \\
\hline & Cup lining & $0.005 \pm 0.014$ & $0.000 \pm 0.000$ & $0.003 \pm 0.010$ & - \\
\hline \multirow{3}{*}{ Fern } & Total nest & $0.003 \pm 0.011$ & $0.018 \pm 0.060$ & $3.483 \pm 3.692$ & - \\
\hline & Outer nest & - & $0.011 \pm 0.036$ & $2.586 \pm 3.057$ & - \\
\hline & Cup lining & $0.003 \pm 0.011$ & - & $0.176 \pm 0.333$ & - \\
\hline \multirow{3}{*}{ Grass } & Total nest & $14.520 \pm 7.614$ & $13.573 \pm 7.982$ & $20.364 \pm 11.750$ & $14.768 \pm 13.511$ \\
\hline & Outer nest & $5.124 \pm 4.256$ & $6.503 \pm 5.476$ & $9.564 \pm 7.716$ & $13.544 \pm 12.562$ \\
\hline & Cup lining & $7.925 \pm 3.999$ & $6.854 \pm 3.992$ & $9.469 \pm 5.461$ & $0.075 \pm 0.064$ \\
\hline \multirow{3}{*}{ Heather } & Total nest & - & $0.022 \pm 0.072$ & $0.306 \pm 0.544$ & - \\
\hline & Outer nest & - & $0.016 \pm 0.054$ & $0.232 \pm 0.431$ & - \\
\hline & Cup lining & - & $0.006 \pm 0.018$ & $0.034 \pm 0.073$ & - \\
\hline \multirow{3}{*}{ Leaves } & Total nest & $5.432 \pm 6.808$ & $0.561 \pm 0.689$ & $1.950 \pm 4.666$ & $1.271 \pm 1.166$ \\
\hline & Outer nest & $2.695 \pm 4.767$ & $0.307 \pm 0.372$ & $1.147 \pm 3.328$ & $0.922 \pm 0.957$ \\
\hline & Cup lining & $1.656 \pm 2.335$ & $0.165 \pm 0.211$ & $0.134 \pm 0.396$ & $0.505 \pm 0.177$ \\
\hline \multirow{3}{*}{ Lichen } & Total nest & - & $14.407 \pm 18.261$ & $0.040 \pm 0.086$ & $0.029 \pm 0.109$ \\
\hline & Outer nest & - & $14.073 \pm 17.993$ & $0.033 \pm 0.067$ & $0.021 \pm 0.100$ \\
\hline & Cup lining & - & $0.030 \pm 0.034$ & $0.007 \pm 0.020$ & - \\
\hline \multirow{3}{*}{ Moss } & Total nest & $7.776 \pm 6.846$ & $14.171 \pm 11.278$ & $9.549 \pm 7.097$ & $9.836 \pm 8.738$ \\
\hline & Outer nest & $7.032 \pm 6.433$ & $12.853 \pm 10.504$ & $8.548 \pm 7.017$ & $9.449 \pm 8.689$ \\
\hline & Cup lining & $0.620 \pm 0.785$ & $1.226 \pm 1.330$ & $0.709 \pm 0.390$ & $0.015 \pm 0.021$ \\
\hline \multirow{3}{*}{ Plant Fibres } & Total nest & $0.151 \pm 0.675$ & - & - & - \\
\hline & Outer nest & $0.146 \pm 0.653$ & - & - & - \\
\hline & Cup lining & $0.003 \pm 0.011$ & - & - & - \\
\hline \multirow{3}{*}{ Roots } & Total nest & $2.546 \pm 4.120$ & $0.213 \pm 0.290$ & $3.908 \pm 5.391$ & $0.287 \pm 0.936$ \\
\hline & Outer nest & $1.386 \pm 2.991$ & $0.128 \pm 0.247$ & $2.843 \pm 4.999$ & $0.282 \pm 0.936$ \\
\hline & Cup lining & $1.023 \pm 1.504$ & $0.056 \pm 0.126$ & $0.682 \pm 0.542$ & - \\
\hline \multirow{3}{*}{ Stems } & Total nest & $6.619 \pm 3.428$ & $14.810 \pm 9.156$ & $12.960 \pm 11.250$ & $11.009 \pm 7.083$ \\
\hline & Outer nest & $4.218 \pm 3.547$ & $12.728 \pm 7.589$ & $9.851 \pm 9.608$ & $8.442 \pm 5.714$ \\
\hline & Cup lining & $0.986 \pm 0.758$ & $0.198 \pm 0.191$ & $1.218 \pm 0.967$ & $0.065 \pm 0.092$ \\
\hline Wood pulp & Total nest & - & - & $79.852 \pm 28.113$ & $43.835 \pm 27.068$ \\
\hline
\end{tabular}




\begin{tabular}{|c|c|c|c|c|c|}
\hline \multirow{4}{*}{ Mineral } & Outer nest & - & - & $11.568 \pm 18.160$ & $3.368 \pm 11.810$ \\
\cline { 2 - 6 } & Cup lining & - & - & $1.251 \pm 1.234$ & - \\
\hline & Total nest & $128.730 \pm 51.720$ & $100.027 \pm 67.352$ & $79.852 \pm 28.113$ & - \\
\cline { 2 - 6 } & Outer nest & $2.979 \pm 3.173$ & $4.707 \pm 4.085$ & $11.568 \pm 18.160$ & - \\
\cline { 2 - 6 } & Cup lining & $0.724 \pm 1.043$ & $1.395 \pm 2.187$ & $1.251 \pm 1.234$ & - \\
\hline \multirow{3}{*}{ Manmade } & Total nest & $0.651 \pm 1.205$ & $1.012 \pm 2.939$ & $0.010 \pm 0.021$ & $0.006 \pm 0.019$ \\
\cline { 2 - 6 } & Outer nest & $0.260 \pm 0.598$ & $0.469 \pm 1.166$ & $0.007 \pm 0.013$ & $0.006 \pm 0.019$ \\
\cline { 2 - 6 } & Cup lining & $0.261 \pm 0.678$ & $0.543 \pm 1.793$ & $0.003 \pm 0.010$ & - \\
\hline
\end{tabular}

**Only two Song Thrush nests contained nest lining material. 
1 Table 6 - Principal component weighing's including standard deviation, eigenvalue, proportion of variance and cumulative proportion of each. Kruskal-Wallis 2 test results for the effect of species on the first three principal Components ( $D F=13$ in each case)

\begin{tabular}{|c|c|c|c|c|c|c|}
\hline & \multicolumn{3}{|c|}{ All species, all nest materials } & \multicolumn{3}{|c|}{ All species, all nest materials except mineral and wood pulp } \\
\hline Variable & PC1 & PC2 & PC3 & PC1 & PC2 & PC3 \\
\hline Arthropod Silk & -0.245 & -0.204 & -0.057 & -0.333 & -0.224 & 0.248 \\
\hline Feather & -0.238 & -0.186 & -0.031 & -0.388 & -0.217 & 0.270 \\
\hline Hair & -0.266 & -0.390 & -0.117 & -0.262 & -0.410 & 0.129 \\
\hline Bark & -0.064 & 0.426 & 0.008 & -0.051 & 0.420 & -0.019 \\
\hline Fern & 0.238 & 0.084 & -0.589 & 0.406 & 0.031 & 0.552 \\
\hline Grass & 0.368 & -0.101 & 0.136 & 0.226 & -0.090 & -0.057 \\
\hline Heather & 0.178 & -0.109 & -0.607 & 0.360 & -0.160 & 0.563 \\
\hline Leaves & 0.016 & 0.540 & -0.048 & -0.014 & 0.523 & 0.082 \\
\hline Lichen & 0.157 & -0.330 & 0.046 & 0.119 & -0.342 & -0.322 \\
\hline Moss & 0.213 & 0.200 & 0.206 & 0.052 & 0.207 & -0.046 \\
\hline Plant Fibres & -0.094 & 0.074 & -0.058 & -0.090 & 0.062 & 0.041 \\
\hline Roots & 0.204 & 0.019 & -0.207 & 0.297 & -0.006 & 0.006 \\
\hline Stems & 0.443 & -0.309 & 0.098 & 0.444 & -0.289 & -0.330 \\
\hline Wood pulp & 0.264 & -0.093 & 0.371 & & & \\
\hline Mineral & 0.438 & 0.054 & -0.036 & & & \\
\hline Manmade & 0.082 & 0.084 & 0.081 & -0.105 & 0.054 & 0.120 \\
\hline Standard Deviation & 1.476 & 1.321 & 1.274 & 1.357 & 1.319 & 1.226 \\
\hline Eigenvalue & 2.178 & 1.744 & 1.622 & 1843 & 1739 & 1504 \\
\hline Proportion of variance & 0.136 & 0.109 & 0.101 & 0.132 & 0.124 & 0.107 \\
\hline Cumulative proportion & 0.136 & 0.245 & 0.346 & 0.132 & 0.256 & 0.363 \\
\hline Levene's test for effect of species & $4.05(<0.001)$ & $3.83(<0.001)$ & $11.12(<0.001)$ & $466(<0.001)$ & $4.20(<0.001)$ & $12.54(<0.001)$ \\
\hline
\end{tabular}




\begin{tabular}{|c|c|c|c|c|c|c|}
\hline Kruskal - Wallis (H(P)) & $133.57(<0.001)$ & $85.72(<0.001)$ & $71.34(<0.001)$ & $137.93(<0.001)$ & $118.72(<0.001)$ & $114.90(<0.001)$ \\
\hline
\end{tabular}

4 
$6 \quad$ Table 7 - Results of discriminant analysis comparing the cup lining (C) and outer nest (N) of twelve species. An overall Wilk’s Lambda and P value comparing the two groups and individual Wilk’s Lambda values determine variables that contribute significantly in the discriminant function. Only components that showed a significant result are included. Common Blackbird, Mistle thrush and Ring Ouzel nests tests were run with and without the mineral component. Only two song thrush nests had cup lining materials and so were excluded from the analysis on the basis of small sample size.

\begin{tabular}{|c|c|c|c|c|c|c|c|c|c|c|c|c|c|c|c|}
\hline & $\begin{array}{c}\text { Mineral } \\
\text { present } \\
?\end{array}$ & Feather & Hair & Bark & Fern & Grass & Heather & Leaves & Lichen & Moss & Roots & Stems & Mineral & Manmade & $\begin{array}{l}\text { Wilk's Lambda } \\
\text { (p) }\end{array}$ \\
\hline $\begin{array}{l}\text { Eurasian Bullfinch } \\
(\mathrm{N}=17)\end{array}$ & & & & & & & & & & & & $\begin{array}{l}0.077 \\
\mathrm{C}<\mathrm{N}\end{array}$ & & & $\begin{array}{c}0.077 \\
(<0.001)\end{array}$ \\
\hline $\begin{array}{l}\text { Common Chaffinch } \\
(\mathrm{N}=11)\end{array}$ & & $\begin{array}{l}0.269 \\
\mathrm{C}>\mathrm{N}\end{array}$ & $\begin{array}{l}0.098 \\
\mathrm{C}>\mathrm{N}\end{array}$ & $\begin{array}{l}0.075 \\
\mathrm{C}<\mathrm{N}\end{array}$ & & & $\begin{array}{l}0.029 \\
\mathrm{C}<\mathrm{N}\end{array}$ & $\begin{array}{l}0.022 \\
\mathrm{C}<\mathrm{N}\end{array}$ & $\begin{array}{l}0.034 \\
\mathrm{C}<\mathrm{N}\end{array}$ & & & $\begin{array}{l}.046 \\
\mathrm{C}<\mathrm{N}\end{array}$ & & $\begin{array}{l}0.058 \\
\mathrm{C}>\mathrm{N}\end{array}$ & $\begin{array}{c}0.022 \\
(<0.001)\end{array}$ \\
\hline $\begin{array}{l}\text { European Goldfinch } \\
(\mathrm{N}=10)\end{array}$ & & $\begin{array}{l}0.052 \\
\mathrm{C}>\mathrm{N}\end{array}$ & & & & & & & & $\begin{array}{l}0.077 \\
\mathrm{C}<\mathrm{N}\end{array}$ & & $\begin{array}{l}0.199 \\
\mathrm{C}<\mathrm{N}\end{array}$ & & & $\begin{array}{c}0.052 \\
(<0.001)\end{array}$ \\
\hline $\begin{array}{l}\text { European } \\
\text { Greenfinch } \\
(\mathrm{N}=5)\end{array}$ & & & & & & & & $\begin{array}{l}0.041 \\
\mathrm{C}>\mathrm{N}\end{array}$ & & & & $\begin{array}{l}0.036 \\
\mathrm{C}<\mathrm{N}\end{array}$ & & & $\begin{array}{c}0.041 \\
(<0.001)\end{array}$ \\
\hline $\begin{array}{l}\text { Hawfinch } \\
(\mathrm{N}=4)\end{array}$ & & & & & & & & & & & & $\begin{array}{l}0.032 \\
\mathrm{C}<\mathrm{N}\end{array}$ & & & $\begin{array}{c}0.032 \\
(<0.001)\end{array}$ \\
\hline $\begin{array}{l}\text { Common Linnet } \\
(\mathrm{N}=11)\end{array}$ & & & $\begin{array}{l}0.161 \\
\mathrm{C}>\mathrm{N}\end{array}$ & & & & & & & & $\begin{array}{l}0.066 \\
\mathrm{C}<\mathrm{N}\end{array}$ & & & $\begin{array}{l}0.091 \\
\mathrm{C}>\mathrm{N}\end{array}$ & $\begin{array}{c}0.066 \\
(<0.001)\end{array}$ \\
\hline $\begin{array}{l}\text { Stonechat } \\
(\mathrm{N}=9)\end{array}$ & & & & & & & & & & $\begin{array}{l}.310 \\
\mathrm{C}<\mathrm{N}\end{array}$ & & & & & $\begin{array}{c}0.310 \\
(<0.001)\end{array}$ \\
\hline $\begin{array}{l}\text { Whinchat } \\
(\mathrm{N}=8)\end{array}$ & & $\begin{array}{l}0.170 \\
\mathrm{C}>\mathrm{N}\end{array}$ & & & & $\begin{array}{l}0.094 \\
C>N\end{array}$ & & & & & $\begin{array}{l}0.061 \\
\mathrm{C}<\mathrm{N}\end{array}$ & & & & $\begin{array}{c}0.061 \\
(<0.001)\end{array}$ \\
\hline $\begin{array}{l}\text { Pied Flycatcher } \\
(\mathrm{N}=25)\end{array}$ & & & & & $\begin{array}{l}0.532 \\
\mathrm{C}<\mathrm{N} \\
\end{array}$ & & & $\begin{array}{l}0.447 \\
\mathrm{C}<\mathrm{N} \\
\end{array}$ & & $\begin{array}{l}0.659 \\
\mathrm{C}<\mathrm{N} \\
\end{array}$ & $\begin{array}{l}0.370 \\
\mathrm{C}>\mathrm{N}\end{array}$ & & & & $\begin{array}{c}0.428 \\
(<0.001) \\
\end{array}$ \\
\hline $\begin{array}{l}\text { European Robin } \\
(\mathrm{N}=12)\end{array}$ & & & & & & $\begin{array}{l}0.822 \\
\mathrm{C}>\mathrm{N}\end{array}$ & & & & & & & & & $\begin{array}{c}0.040 \\
(0.040)\end{array}$ \\
\hline \multirow[t]{2}{*}{$\begin{array}{l}\text { Common Blackbird } \\
(\mathrm{N}=20)\end{array}$} & Yes & & & & & & & & & $\begin{array}{l}0.623 \\
\mathrm{C}<\mathrm{N}\end{array}$ & & $\begin{array}{l}0.461 \\
\mathrm{C}<\mathrm{N}\end{array}$ & $\begin{array}{l}0.334 \\
\mathrm{C}<\mathrm{N}\end{array}$ & & $\begin{array}{c}0.334 \\
(<0.001)\end{array}$ \\
\hline & No & & & & & & & & & $\begin{array}{l}1 \\
0.623 \\
\mathrm{C}<\mathrm{N}\end{array}$ & & $\begin{array}{l}0.461 \\
\mathrm{C}<\mathrm{N}\end{array}$ & & & $\begin{array}{c}0.461 \\
(<0.001)\end{array}$ \\
\hline \multirow[t]{2}{*}{$\begin{array}{l}\text { Mistle Thrush } \\
(\mathrm{N}=11)\end{array}$} & Yes & $\begin{array}{l}0.119 \\
\mathrm{C}<\mathrm{N}\end{array}$ & & & & & & & $\begin{array}{l}0.185 \\
\mathrm{C}<\mathrm{N}\end{array}$ & $\begin{array}{l}0.286 \\
\mathrm{C}<\mathrm{N}\end{array}$ & & $\begin{array}{l}0.399 \\
\mathrm{C}<\mathrm{N}\end{array}$ & $\begin{array}{l}0.072 \\
\mathrm{C}<\mathrm{N}\end{array}$ & & $\begin{array}{c}0.072 \\
(<0.001)\end{array}$ \\
\hline & No & $\begin{array}{l}0.119 \\
\mathrm{C}<\mathrm{N}\end{array}$ & & & & & & & $\begin{array}{l}0.185 \\
\mathrm{C}<\mathrm{N}\end{array}$ & $\begin{array}{l}0.286 \\
\mathrm{C}<\mathrm{N}\end{array}$ & & $\begin{array}{l}0.399 \\
\mathrm{C}<\mathrm{N}\end{array}$ & & & $\begin{array}{c}0.119 \\
(<0.001)\end{array}$ \\
\hline $\begin{array}{l}\text { Ring Ouzel } \\
(\mathrm{N}=9)\end{array}$ & $\begin{array}{c}\text { Yes } \\
\text { and No }\end{array}$ & & $\begin{array}{l}0.103 \\
\mathrm{C}<\mathrm{N}\end{array}$ & $\begin{array}{l}0.135 \\
\mathrm{C}<\mathrm{N}\end{array}$ & & $\begin{array}{l}0.362 \\
\mathrm{C}>\mathrm{N}\end{array}$ & & & & $\begin{array}{l}0.205 \\
\mathrm{C}<\mathrm{N}\end{array}$ & & & & & $\begin{array}{c}0.138 \\
(0.133)\end{array}$ \\
\hline
\end{tabular}

